\title{
Metabolismo mineral y óseo: visión general y sus métodos de medición
}

\author{
Bone and mineral metabolism: Overview \\ and methods of measurement

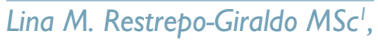 \\ Joel Arévalo-Novoa MD², \\ Martín Toro-Ramos MD
}

\begin{abstract}
Resumen: las concentraciones plasmáticas de calcio, fósforo y magnesio dependen del balance neto del depósito mineral óseo y su resorción, la absorción intestinal y la excreción renal. Estos iones son importantes para muchas funciones biológicas y celulares como la señalización intracelular, la transmisión neural y la contracción muscular. Las principales hormonas que regulan la homeostasis de estos procesos son la hormona paratiroidea (PTH), la calcitonina, la 1,25-dihidroxi vitamina D y el factor de crecimiento fibroblástico-23 (FGF- 23). A través de sus acciones e interacciones sobre el hueso, el riñón y el tracto gastrointestinal las hormonas calciotrópicas (la hormona paratiroidea, la calcitonina y los metabolitos de la vitamina D, especialmente la 1,25-dihidroxi vitamina D) actúan para mantener la calcemia dentro de un rango normal, lo que permite el funcionamiento óptimo de muchos procesos fisiológicos dependientes de calcio. Los avances en las técnicas de análisis de los diferentes componentes del metabolismo mineral y óseo son útiles en la comprensión de su papel en la salud y la enfermedad. En este artículo se ofrece una revisión de los aspectos fisiológicos, clínicos y analíticos de estos protagonistas en el metabolismo óseo y mineral.
\end{abstract}

Palabras clave: calcio, fósforo, metabolismo, remodelación ósea, resorción ósea, hormona paratiroidea, calcitonina, vitamina $D$, fosfatoninas.

Abstract: The plasma concentrations of calcium, phosphate, and magnesium are dependent on the net balance of bone mineral deposition and resorption, intestinal absorption, and renal excretion. These ions are important for many biologic and cellular functions such as intracellular signaling,

\footnotetext{
' Médica, especialista en Medicina Interna y Endocrinología Clínica y Metabolismo. Endocrinóloga Clínica Medellín y Laboratorio Clínico Hematológico. Docente asociada Universidad CES. Medellín, Colombia. Estudiante de MSc en Oncología, Fundación Antonio Prudente, Hospital A.C. Camargo Cancer Center. São Paulo, Brasil

${ }^{2}$ Médico, especialista en Cirugía General. Residente de Cirugía de Cabeza y Cuello, Fundación Antonio Prudente, Hospital A.C. Camargo Cancer Center. São Paulo, Brasil

${ }^{3}$ Médico, especialista en Pediatría y Endocrinología Pediátrica. Endocrinólogo IPS Universitaria y Sura EPS. Docente de cátedra Universidad de Antioquia. Medellín, Colombia.

Conflicto de intereses: los autores declaran que no tienen conflicto de intereses Medicina \& Laboratorio 2015; 21: 51 1-538

Módulo I (La Clínica y el Laboratorio), número I I 3. Editora Médica Colombiana S.A. $2015^{\circ}$

Recibido el 09 de diciembre de 2015; aceptado el 26 de diciembre de 2015
} 
neural transmission, and muscle contraction. The principal hormones regulating the homeostasis of these processes are parathyroid hormone (PTH), calcitonin, 1.25-dihydroxy vitamin D and fibroblast growth factor-23 (FGF-23). Through their actions on bone, kidney and the gastrointestinal tract, the calciotropic hormones (parathyroid hormone, calcitonin, and vitamin D metabolites, especially the 1.25-dihydroxy vitamin D) act to maintain serum calcium within a normal range, that allows the optimally function of many calcium-requiring physiological functions. The improved procedures for the assays of different components of mineral and bone metabolism are useful in understanding their role in health and disease. This paper provides a review of the physiology, clinical and analytic aspects of these protagonists in bone and mineral metabolism.

Key words: calcium, phosphorus, metabolism, bone remodeling, bone resorption, parathyroid hormone, calcitonin, vitamin $D$, phosphatonins.

Restrepo-Giraldo LM, Arévalo-Novoa J, Toro-Ramos M. Metabolismo mineral y óseo: visión general y sus métodos de medición. Medicina \& Laboratorio 2015; 21: 511 -538.

E esqueleto es un órgano metabólicamente activo que experimenta una remodelación continua a través de la vida, necesaria para mantener su integridad estructural y para cumplir con las funciones metabólicas como lugar de almacenamiento del calcio y el fósforo. La remodelación esquelética puede ser desencadenada por cambios en las fuerzas mecánicas, microtraumas y por respuestas hormonales a los cambios en los niveles circulantes de calcio y fósforo [1-4].

El hueso puede clasificarse en dos tipos: cortical o compacto y trabecular o esponjoso. El hueso cortical tiene funciones mecánicas, de soporte y protección, y constituye el 80\% de la masa esquelética. El hueso trabecular corresponde al 20\% restante, funciona como depósito de células hematopoyéticas y, gracias a su estructura en panal de abejas, provee una amplia superficie para el intercambio mineral [2]. El tejido óseo es muy dinámico y compuesto por varios subtipos celulares; los osteocitos, las células más abundantes en el hueso, son osteoblastos maduros y corresponden al 95\% de las células del hueso. Lejos de ser quiescentes e inactivos, los osteocitos coordinan la formación de hueso durante el crecimiento y el mantenimiento de un esqueleto sano para la locomoción y la protección de los órganos. Los osteocitos orquestan el trabajo de los osteoblastos, que forman el hueso, y los osteoclastos, que reabsorben el hueso, mediante la producción de factores que permiten que el esqueleto se adapte a las necesidades mecánicas y los cambios hormonales [5]. Por su parte, los osteoclastos producen hidrogeniones para movilizar los minerales y enzimas proteolíticas para hidrolizar la matriz orgánica y los osteoblastos sintetizan la matriz orgánica (osteoide) y controlan la mineralización de esta nueva matriz [3].

Las concentraciones plasmáticas de calcio, fósforo y magnesio dependen del balance entre la formación y la resorción mineral ósea, la absorción intestinal y la excreción renal. Las principales hormonas que regulan este proceso son la paratohormona (PTH), la calcitonina y la 1,25-dihidroxi vitamina $D$, las cuales pueden ser estimuladas e inhibidas bajo ciertas condiciones (véase tabla I) [6,7]. A continuación se revisará el papel fisiológico, la regulación y los métodos de medición de los principales minerales y hormonas que participan en el metabolismo óseo y fosfocálcico. 


\begin{tabular}{|c|c|c|c|c|c|}
\hline Regulador & Estímulo & Inhibición & Efecto óseo & Efecto renal & $\begin{array}{l}\text { Efecto tracto } \\
\text { gastrointestinal }\end{array}$ \\
\hline Paratohormona & $\begin{array}{l}\text { ICa++ libre } \\
\text { Fósforo } \\
\text { sérico }\end{array}$ & $\begin{array}{l}\text { Ta++ } \\
\text { Trtamina D } \\
\text { IMagnesio sérico }\end{array}$ & |Resorción ósea & $\begin{array}{l}\text { Reabsorción de } \mathrm{Ca}++ \\
\text { en túbulo contorneado } \\
\text { distal } \\
\text { Síntesis de vitamina D }\end{array}$ & $\begin{array}{l}\text { PAbsorción } \\
\text { gastrointestinal }\end{array}$ \\
\hline Vitamina D & $\begin{array}{l}\text { PParatohormona } \\
\text { (estimula la } \\
\text { síntesis renal) }\end{array}$ & & †Resorción ósea & & $\begin{array}{l}\text { Absorción } \\
\text { gastrointestinal }\end{array}$ \\
\hline $\begin{array}{l}\text { Calcitonia } \\
\text { (débil) }\end{array}$ & & & Resorción ósea & $\begin{array}{l}\text { Excreción renal } \\
\text { de Ca++ }\end{array}$ & \\
\hline
\end{tabular}

\section{Minerales óseos}

\section{Calcio}

\section{Distribución y formas}

El calcio es el quinto elemento más común y el catión más prevalente en el cuerpo humano. Un individuo sano posee aproximadamente I kg a I,3 kg de calcio, el 99\% de este se encuentra en forma de hidroxiapatita en el esqueleto y el $1 \%$ restante en el líquido extracelular y en los tejidos blandos. Además, menos del I\% del contenido esquelético de calcio se encuentra disponible para el intercambio libre con el líquido extracelular [7].

El calcio sérico existe en tres formas diferentes: a) libre o ionizado: corresponde a la forma metabólicamente activa y representa el 50\% del calcio sérico total, b) en complejos con diferentes aniones, como el bicarbonato, el lactato, el fosfato y el citrato, y corresponde al $10 \%$ del calcio sérico y c) unido a proteínas, corresponde al $40 \%$ del calcio sérico, del cual aproximadamente $80 \%$ está asociado a la albúmina. Tanto el calcio ionizado como el unido en complejos con aniones es dializable. Debido a que el calcio ionizado se une a sitios cargados negativamente compite con los iones de hidrógeno por los sitios de unión a proteínas, por lo tanto, esta unión es dependiente del pH. De esta manera, la alcalosis promueve la unión a proteínas mientras que la acidosis disminuye esta asociación e incrementa el porcentaje de calcio libre. Además, las concentraciones de calcio sérico dependen también de la concentración de proteínas plasmáticas, principalmente la albúmina [6].

\section{Función}

Además de su importancia en la mineralización esquelética el calcio desempeña un papel vital en varios procesos fisiológicos básicos como la coagulación sanguínea, la transmisión nerviosa, la actividad enzimática, como tampón en el equilibrio ácido-básico y en el mantenimiento del tono muscular normal y la excitabilidad del músculo cardiaco y esquelético. El calcio funciona como un activador de la transducción de señales intracelulares, es esencial para la biosíntesis del ADN y el ARN, es indispensable en la síntesis glandular y para la regulación de la secreción de las glándulas endocrinas y exocrinas [8]. 


\section{Homeostasis}

La concentración extracelular de calcio ionizado es mantenida dentro de un estrecho rango de aproximadamente I,25 mmol/L. Las glándulas paratiroides, a través de su receptor de membrana sensible al calcio, pueden sensar los descensos en la calcemia y secretar inmediatamente la paratohormona. La paratohormona estimula los osteoblastos y sus precursores para producir RANKL (ligando del receptor activador del factor nuclear $\kappa B$ ). Esta sustancia, miembro de la superfamilia del factor de necrosis tumoral, activa el receptor RANK (receptor activador del factor nuclear $\kappa B$ ) expresado en los osteoclastos y sus precursores. La unión de RANKL y RANK promueve la actividad de los osteoclastos y prolonga su supervivencia al inhibir la apoptosis [9].

La resorción de la matriz extracelular libera calcio y fósforo al líquido extracelular. Al mismo tiempo la paratohormona actúa en los riñones para estimular la excreción de fosfato y la reabsorción de calcio en la nefrona distal, devolviendo el calcio sérico a su concentración normal. Se ha sugerido que para que estas acciones sean eficientes se requiere de concentraciones suficientes de la I,25-dihidroxi vitamina D [6] (véase figura I).

El calcio se absorbe en el duodeno y en el yeyuno superior por un proceso de transporte activo. El principal estímulo para la absorción intestinal es la vitamina $D$, pero también se encuentra estimulado por la hormona de crecimiento, el aumento de la ingesta de proteínas y el medio intestinal ácido. Por su parte, el cortisol y la excesiva alcalinización del contenido intestinal son inhibitorios para la absorción del calcio [6] (véase figura I).

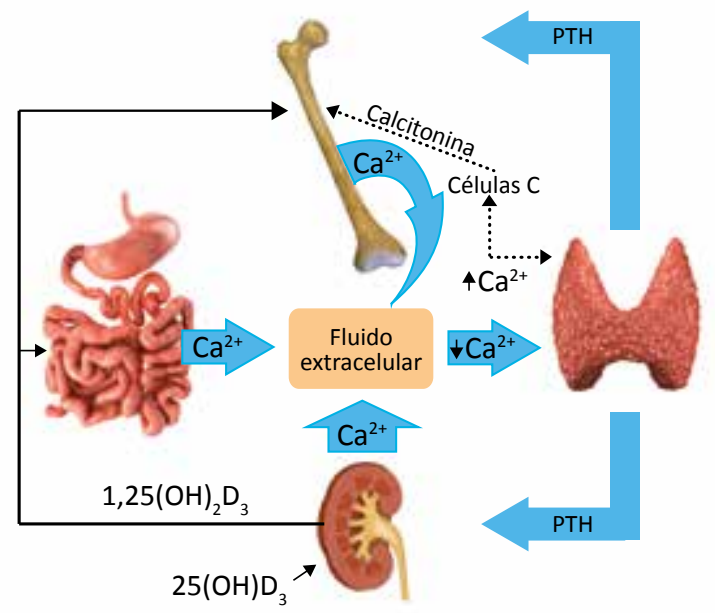

Figura I. Metabolismo del calcio. I,25(OH) $\mathrm{D}_{3}=1,25$-dihidroxi vitamina $\mathrm{D}_{3}, 25(\mathrm{OH}) \mathrm{D}_{3}=25$-hidroxi vitamina $\mathrm{D}_{3}$, PTH=paratohormona.

La principal vía de eliminación del calcio es la excreción renal, que varía entre 100 mg/día y 200 $\mathrm{mg} / \mathrm{día}$. En individuos sanos, amplias variaciones en la ingestión del calcio tienen poco efecto en la excreción de calcio urinario. La excreción urinaria de calcio se aumenta por hipercalcemia, privación de fosfatos, acidosis y por los glucocorticoides. Entretanto, la paratohormona, los diuréticos tiazídicos y probablemente la vitamina D disminuyen la caliciuria [ I] (véase figura I). 


\section{Técnicas analíticas}

El calcio sérico total incluye la fracción libre y la unida a la albúmina. De forma alternativa se puede medir sólo el calcio ionizado. El calcio total es más fácil de medir en el laboratorio, pero su resultado debe ser interpretado según el contexto clínico. Por ejemplo, pacientes con enfermedades malignas frecuentemente presentan hipoalbuminemia, condición que puede generar resultados de calcio falsamente bajos. Por lo tanto, el calcio sérico total (expresado en $\mathrm{mg} / \mathrm{dL}$ ) siempre se debe corregir según la concentración de la albúmina aplicando la siguiente ecuación [10].

\section{Calcio total $(\mathrm{mg} / \mathrm{dL})$ corregido $=$ Calcio total medido+[(Albúmina normal-Albúmina del paciente) $\times 0,8]$}

Usualmente se usa como valor de referencia en la fórmula anterior una albúmina de 4,4.

\section{Calcio total y calcio ionizado}

Se han descrito varias técnicas para medir el calcio total, pero sólo tres métodos son usados comúnmente: a) el análisis colorimétrico con indicadores metalocromáticos, b) la espectrometría de absorción atómica (AAS; del inglés, Atomic Absorption Spectroscopy) y c) la potenciometría indirecta. El método de referencia para determinar el calcio sérico total es la espectrometría de absorción atómica, pero a pesar de que tiene mayor exactitud y precisión, comparada con otros métodos, pocos laboratorios continúan usándolo pues para analizar un gran número de muestras se requieren métodos automáticos no disponibles para esta técnica. Por lo tanto, el calcio total se mide usualmente por determinación espectrofotométrica del calcio unido a indicadores metalocrómicos [10-12].

La potenciometría indirecta consiste en un electrodo selectivo por el calcio que evalúa una muestra, que también es medida con un electrodo selectivo por el sodio, en donde las concentraciones de calcio son proporcionales a la diferencia de potencial entre estos electrodos. Los instrumentos con electrodos selectivos por el calcio proveen determinaciones exactas, precisas y automáticas del calcio ionizado [6].

\section{Intervalos de referencia}

El intervalo de referencia del calcio sérico total en adultos sanos varía entre 8,8 mg/dL a 10,3 $\mathrm{mg} / \mathrm{dL}(2,20 \mathrm{mmol} / \mathrm{L}$ a $2,58 \mathrm{mmol} / \mathrm{L})$. El suero es la muestra preferida para la determinación del calcio, pero el plasma heparinizado también es aceptable. Otros anticoagulantes como el citrato, el oxalato y el EDTA (ácido etilendiaminotetraacético) interfieren con los métodos comúnmente usados para la determinación de calcio sérico. Otros factores que interfieren con los métodos colorimétricos incluyen la hemólisis, la ictericia, la lipemia, la paraproteinemia y el magnesio $[1,6]$.

El intervalo de referencia para el calcio ionizado en adultos sanos es 4,6 mg/dL a 5,3 mg/dL ( I, I $6 \mathrm{mmol} / \mathrm{L}$ a I,32 mmol/L). La muestra puede ser sangre total, plasma heparinizado o suero. El espécimen debe ser recolectado en forma anaeróbica, transportado en hielo y almacenado a $4{ }^{\circ} \mathrm{C}$ para prevenir la pérdida del dióxido de carbono, reducir la glicólisis y estabilizar el pH (los cambios en el pH alteran la fracción de calcio ionizado). La técnica de recolección de la muestra apropiada es fundamental para asegurar la exactitud del resultado, específicamente, el 
uso de torniquete por tiempo prolongado puede hacer que el $\mathrm{pH}$ descienda en el sitio de la toma de muestra, que resultaría en valores falsamente elevados [I I].

El intervalo de referencia para el calcio urinario varía según la dieta. Los individuos con dieta usual eliminan hasta 300 mg/día (7,49 mmol/día), por lo que se acepta que la excreción debe ser menor a $4 \mathrm{mg} / \mathrm{kg} / \mathrm{d}$ í. Los especímenes deben ser recolectados con acidificación apropiada para prevenir la precipitación de las sales de calcio [6].

\section{Fósforo}

\section{Distribución}

El contenido corporal total de fósforo en adultos sanos está alrededor de $700 \mathrm{~g}$ a 800 g. Aproximadamente $80 \%$ al $85 \%$ se encuentra en el esqueleto, el 15\% restante se encuentra en el líquido extracelular en forma de fosfato inorgánico y dentro de las células como fosfatos orgánicos (p. ej. en los fosfolípidos, los ácidos nucleicos y como adenosín trifosfato). El esqueleto contiene principalmente fosfato inorgánico, predominantemente como hidroxiapatita y fosfato de calcio [13].

En la sangre el fósforo orgánico está localizado principalmente en los eritrocitos, pues el plasma contiene principalmente fosfato inorgánico. Aproximadamente dos tercios del fósforo sanguíneo es orgánico, mientras que el fósforo inorgánico representa solo $3 \mathrm{mg} / \mathrm{dL}$ a $4 \mathrm{mg} / \mathrm{dL}$ del total de $12 \mathrm{mg} / \mathrm{dL}$. El fosfato sérico inorgánico circula como anión divalente $\left(\mathrm{HPO}_{4}^{2-}\right)$ y monovalente $\left(\mathrm{H}_{2} \mathrm{PO}_{4}^{-}\right)$; ambos tampones muy importantes. La relación $\mathrm{H}_{2} \mathrm{PO}_{4}^{-}: \mathrm{HPO}_{4}^{2-}$ es dependiente del $\mathrm{pH}$ y varía entre I, I en acidosis, I,4 a pH fisiológico y I,9 en alcalosis. Aproximadamente el 10\% del fósforo sérico está unido a proteínas, 35\% forma compuestos con el sodio, el calcio y el magnesio, y el 55\% restante permanece libre. En escenarios clínicos sólo se mide usualmente el fósforo inorgánico [3].

\section{Función}

De manera adicional a su rol en el esqueleto, el fósforo tiene funciones fundamentales intra y extracelulares. El fosfato es un constituyente importante de los ácidos nucleicos, los fosfolípidos, las fosfoproteínas, compuestos de alta energía como el adenosín trifosfato (ATP) y cofactores como la nicotinamida adenina dinucleótido fosfato en su forma reducida (NADPH). El fósforo también está involucrado en el metabolismo intermedio y como parte de varios sistémicas enzimáticos; además, es esencial para la contractibilidad muscular, las funciones neurológicas, el transporte de electrones y el transporte de oxígeno por la hemoglobina (2,3-difosfoglicerato) [6].

\section{Homeostasis}

La mayoría del fosfato se deriva de la dieta, pero una parte se deriva del metabolismo óseo. El fósforo es ubicuo en la dieta, la ingesta promedio para los adultos está alrededor de 800 mg a 1.400 mg diarios. Aproximadamente entre el $60 \%$ y el $80 \%$ del fósforo se absorbe en el intestino, principalmente por transporte pasivo; sin embargo, también existe un mecanismo de transporte activo estimulado por la 1,25-dihidroxi vitamina D. El fósforo es libremente filtrado en los glomérulos y más del $80 \%$ de este es reabsorbido en el túbulo proximal y una pequeña cantidad en el túbulo distal. La reabsorción proximal ocurre por transporte pasivo acoplado con el sodio (cotransportador $\mathrm{Na}-\mathrm{P}$ ), regulado principalmente por la paratohormona y la in- 
gesta de fósforo, donde la restricción de fósforo incrementa la reabsorción [3]. Por su parte, la paratohormona induce la fosfaturia mediante la unión a receptores específicos en la membrana basolateral que activan dos vías principales: la vía de la adenilato ciclasa/adenosín monofosfato cíclico (AMPc)/proteína quinasa A y la vía fosfolipasa C/calcio/proteína quinasa C; ambas inhiben el contransportador Na-P principalmente en el túbulo proximal [14].

La paratohormona con su efecto fosfatúrico desciende los valores de fosfato mientras que la vitamina D y la hormona de crecimiento elevan sus niveles; la vitamina D mediante el estímulo de la absorción intestinal y la reabsorción renal del fósforo y la hormona de crecimiento, regulador del crecimiento esquelético, a través de la reducción de la excreción renal del fósforo [6].

Otra cascada de regulación del fosfato que se ha descrito y hasta ahora se entiende solo parcialmente involucra el factor de crecimiento fibroblástico-23 (FGF-23; del inglés, Fibroblast Growth Factor-23), una hormona producida en los osteocitos, los osteoblastos, los pericitos de la médula, el timo y los ganglios linfáticos $[15,16]$. Los niveles elevados de FGF-23 producen hiperfosfaturia, principalmente al inhibir los canales de reabsorción del fósforo dependientes de sodio; además, inhibe la absorción intestinal del fósforo de forma indirecta al inhibir la transformación de la 25-hidroxi vitamina $D$ en la 1,25-dihidroxi vitamina D, por la l $\alpha$-hidroxilasa del túbulo proximal [15]. Las mutaciones que afectan el FGF-23, el gen regulador del fosfato con homologías con las endopeptidasas (PHEX; del inglés, phosphate regulating gene with homologies to endopeptidases) y la fosfoglicoproteína de matriz extracelular (MEPE; del inglés, matrix extracellular phosphoglycoprotein) se han implicado en el aumento de la fosfaturia y con varias alteraciones en la mineralización, incluyendo el raquitismo hipofosfatémico hereditario y la calcinosis tumoral familiar hiperfosfatémica $[16,17]$.

\section{Técnicas analíticas}

Los métodos más comúnmente usados para la determinación del fosfato inorgánico están basados en la reacción del fosfato con el molibdato de amonio para formar complejos de fosfomolibdato. El complejo no reducido puede medirse con luz ultravioleta; principio que ha sido adoptado por la mayoría de pruebas automatizadas. También se pueden usar sustancias reductoras para crear azul de molibdeno que se puede medir por métodos colorimétricos, pero las ventajas de medir los compuestos no reducidos son la rapidez, la simplicidad y la estabilidad. La formación de complejos con molibdeno es dependiente del pH e influenciada por la concentración de proteínas [18].

También se ha descrito un método enzimático donde el fósforo sufre reacciones enzimáticas sucesivas y el NADPH producido puede ser cuantificado por fluorometría o espectrofotometría. Esta reacción se produce a un pH neutro, permitiendo la medición de fósforo inorgánico en la presencia de fosfato orgánico inestable $[6,18]$.

Para la medición del fosfato se prefiere el suero pues la mayoría de anticoagulantes, a excepción de la heparina, interfieren con los resultados y generan valores falsamente bajos. Los niveles de fósforo aumentan por el almacenamiento prolongado de las células a temperatura ambiente. Las muestras hemolizadas son inaceptables porque los eritrocitos contienen altos niveles de esteres orgánicos que se hidrolizan a fosfato orgánico, ocasionando valores falsamente elevados [6]. 


\section{Intervalo de referencia}

En adultos sanos el fósforo sérico varía entre $2,8 \mathrm{mg} / \mathrm{dL}$ y $4,5 \mathrm{mg} / \mathrm{dL}(0,89 \mathrm{mmol} / \mathrm{L}$ y I,44 $\mathrm{mmol} / \mathrm{L})$. Las concentraciones más altas ocurren durante el crecimiento $(4 \mathrm{mg} / \mathrm{dL}$ a $7 \mathrm{mg} / \mathrm{dL}$ o I,29 mmol/L a 2,26 mmol/L). El mejor momento para la medición del fósforo es durante la mañana en ayunas, debido a la variación diurna (mayores valores en la tarde y en la noche), así como la reducción del fosfato sérico después de las comidas. Los valores están influenciados por la ingesta alimentaria, las comidas y el ejercicio físico [13].

\section{Magnesio \\ Distribución}

El magnesio es el cuarto catión más abundante en el cuerpo humano y el segundo más frecuente en el compartimento intracelular. El contenido corporal total de magnesio en un adulto se encuentra alrededor de 1.000 mmol o 22,66 g, de los cuales el 50\% al 60\% se encuentran en el hueso y el $40 \%$ al $50 \%$ en los tejidos blandos. Un tercio del magnesio esquelético está disponible para el intercambio y, posiblemente, sirve como reserva para mantener su concentración extracelular [13].

Solo el $1 \%$ del magnesio total se encuentra en el líquido extracelular. En el suero, aproximadamente el 55\% del magnesio se encuentra ionizado o en forma libre $\left(\mathrm{Mg}^{++}\right)$, el 30\% está asociado a proteínas, principalmente la albúmina, y el I5\% forma complejos con el fosfato, el citrato y otros aniones. Aproximadamente el $99 \%$ del magnesio corporal total está en la matriz ósea (60\%) o intracelular (40\%). Dentro de las células el magnesio se encuentra compartimentalizado, unido a proteínas y otros aniones. Aproximadamente el $80 \%$ del magnesio citosólico está unido al ATP. Además, se encuentran cantidades significativas de magnesio en el núcleo, la mitocondria y el retículo endoplásmico. El magnesio libre intracelular probablemente es un importante cofactor enzimático [19].

\section{Función}

El magnesio es esencial para la función de más de 300 enzimas celulares, incluidas aquellas relacionadas con la transferencia de grupos fosfato, todas las reacciones que requieren ATP, cada paso relacionado con la replicación y transcripción del ADN y la traducción del ARN. Este catión también se requiere para el metabolismo energético de la célula y por su importante papel en la estabilización de la membrana, la conducción nerviosa, el transporte de iones y la actividad de los canales de calcio. Además, el magnesio es indispensable para mantener la concentración intracelular de potasio, regulando el movimiento de potasio a través de las membranas de las células miocárdicas [19].

La deficiencia de magnesio puede ocasionar alteraciones metabólicas y consecuencias clínicas como trastornos hidroelectrolíticos refractarios (hipokalemia) y arritmias cardiacas, observadas en situaciones de estrés como la cirugía cardiaca [13].

\section{Homeostasis}

El magnesio corporal total depende principalmente de la absorción gastrointestinal y la excreción renal. La ingesta diaria de magnesio fluctúa entre 300 mg/día y 350 mg/día y la absorción 
intestinal es inversamente proporcional a la cantidad ingerida. Los factores que regulan la absorción intestinal de magnesio aún no han sido esclarecidos completamente [19].

El riñón es el principal regulador del magnesio. La excreción renal se encuentra alrededor de I 20- 140 mg/24 horas en una persona con dieta normal. Aproximadamente el 70\% al 80\% del magnesio plasmático se filtra a través de la membrana glomerular. La reabsorción tubular de magnesio es diferente a la de los otros iones porque el túbulo proximal tiene una participación limitada. El 60\% al 70\% de la reabsorción de $\mathrm{Mg}^{++}$se lleva a cabo en la porción gruesa de la rama ascendente del asa de Henle. Aunque el túbulo distal reabsorbe solo el $10 \%$ del $\mathrm{Mg}^{++}$, este es el principal sitio de regulación del magnesio [20,2l].

Muchos factores, hormonales y no hormonales (p. ej. la paratohormona, la calcitonina, el glucagón, la vasopresina, la restricción de magnesio, los cambios ácido-base y el agotamiento de potasio) influencian la reabsorción tanto en el asa de Henle como en el túbulo distal. Sin embargo, el mayor regulador de la reabsorción es la concentración plasmática de $\mathrm{Mg}^{++}$en sí misma, al parecer mediada por receptores sensibles al $\mathrm{Ca}^{++} / \mathrm{Mg}^{++}$localizados en las células del lado capilar de la porción gruesa de la rama ascendente. Otros factores que desempeñan un papel importante son la concentración de calcio y la tasa de reabsorción de cloruro de sodio [2।].

En la deficiencia de magnesio los niveles séricos disminuyen, lo que lleva a la reducción en su excreción urinaria; más tarde, los depósitos óseos se ven afectados. Debido a que el suero contiene solo el $1 \%$ del $\mathrm{Mg}^{++}$total, sus concentraciones no reflejan en forma confiable los depósitos de este catión. En general, un bajo nivel puede indicar deficiencia; sin embargo, un resultado normal debe ser interpretado con cautela porque no excluye una deficiencia subyacente. Se considera que la evaluación más precisa del estado de magnesio es la prueba de carga, donde se administra magnesio intravenoso y en la que los pacientes con deficiencia retienen una mayor proporción de la carga y excretan menor cantidad en la orina que los individuos normales [22]. Esta prueba no se utiliza frecuentemente en la clínica por su poca practicidad.

\section{Técnicas analíticas}

\section{Magnesio total}

Para la determinación del magnesio se prefiere el suero porque los anticoagulantes interfieren con la mayoría de los procesos de medición. El magnesio usualmente se mide por fotometría, aunque el método de referencia es la espectrofotometría por absorción atómica. La mayoría de los laboratorios usan un método fotométrico en un sistema automatizado. Estos métodos usan indicadores metalocrómicos u otros colorantes que cambian el color al unirse selectivamente con el magnesio de la muestra [I I]. Estas mediciones se pueden afectar por la concentración elevada de bilirrubina, que puede subestimar en forma significativa el contenido de magnesio de la muestra [19].

\section{Magnesio ionizado o libre}

El magnesio ionizado o libre se puede medir con electrodos selectivos que han sido incorporados en varios equipos comerciales [23]; sin embargo, estos electrodos además de magnesio pueden medir calcio y requieren una corrección quimiométrica para calcular los verdaderos niveles de magnesio libre en la muestra. Muchos estudios han mostrado diferencias en las mediciones del magnesio ionizado entre los diferentes equipos, lo que se atribuye a la interferencia con el calcio libre de la muestra, la especificidad insuficiente y la falta de estandarización de los calibradores [1 1,24]. 
Los cambios en el magnesio ionizado asociados a las alteraciones del $\mathrm{pH}$ son similares a las que ocurren con el calcio, aunque no están tan bien caracterizadas. Con un aumento del pH disminuye el calcio ionizado y con el descenso del pH el magnesio ionizado aumenta [12].

\section{Intervalo de referencia}

El rango de magnesio sérico total en adultos sanos se encuentra entre $1,7 \mathrm{mg} / \mathrm{dL}$ y $2,2 \mathrm{mg} / \mathrm{dL}(\mathrm{l}, 5$ $\mathrm{mEq} / \mathrm{L}$ y $1,9 \mathrm{mEq} / \mathrm{L} ; 0,75 \mathrm{mmol} / \mathrm{L}$ y $0,95 \mathrm{mmol} / \mathrm{L})$. No parecen existir diferencias significativas asociadas al sexo o la edad. La concentración de magnesio en los eritrocitos es aproximadamente tres veces mayor que la concentración sérica. El intervalo de referencia para el magnesio ionizado depende del equipo usado para su medición pero generalmente varía entre 0,44 mmol/L y 0,6 mmol/L [ I l ] .

\section{Hormonas que regulan el metabolismo mineral}

\section{Paratohormona}

\section{Síntesis}

La paratohormona es sintetizada y secretada por las células principales de la glándula paratiroides. En su forma intacta es un polipéptido de cadena única que consiste en 84 aminoácidos con una masa molecular de $9.500 \mathrm{Da}$ (véase figura 2). Esta hormona se deriva de un precursor más largo, la pre-pro-paratohormona (pre-pro-PTH) de 155 aminoácidos que sufre dos clivajes sucesivos en las secuencias aminoterminales ( $\mathrm{N}$-terminal), dando lugar a un precursor intermedio, la pro-paratohormona (pro-PTH), y luego a la hormona como tal. Toda la pro-paratohormona que llega a la circulación es convertida de inmediato en paratohormona y otros productos [7].

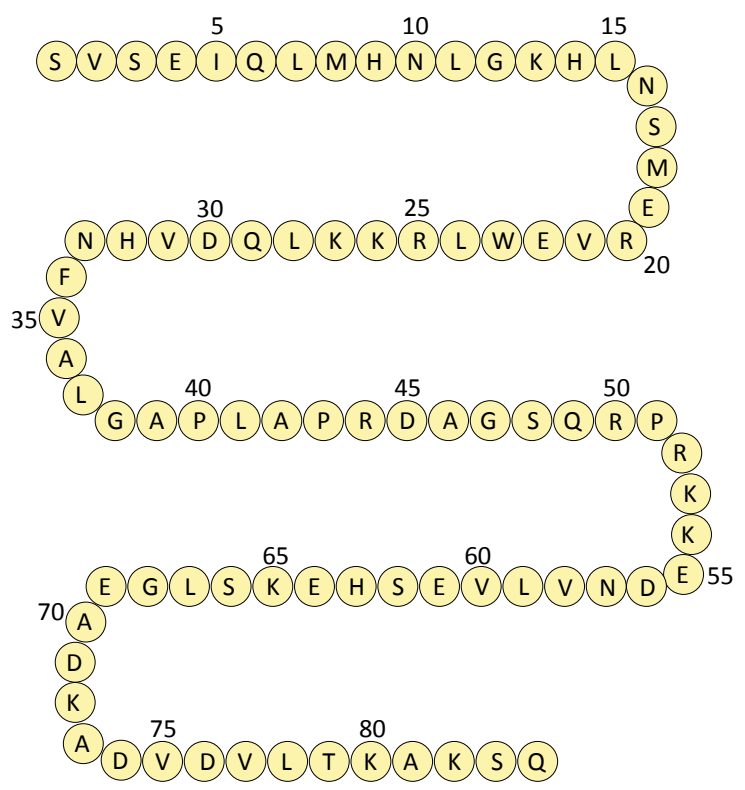

Figura 2. Estructura de la paratohormona humana. 
La paratohormona biológicamente activa es la I-84 (PTH I-84), la cual ejerce su efecto a través de la interacción de sus primeros 34 aminoácidos de la porción N-terminal con el receptor tipo I (PTHIR) para la hormona paratiroidea (PTH) y el péptido relacionado con la hormona paratiroidea (PTH-rP). Algunos fragmentos que contienen porciones de la molécula tanto en el carboxilo terminal (C-terminal) como el $\mathrm{N}$-terminal, producidos por la degradación intraglandular o periférica de la hormona, están presentes en la circulación [25].

El metabolismo de la paratohormona es complejo y se producen muchos fragmentos de actividad y reactividad biológica variable. En el hígado por el clivaje de la paratohormona intacta se producen fragmentos y péptidos más pequeños que se liberan a la circulación. La vida media de la paratohormona I-84 es de dos a cuatro minutos debido a su rápida depuración hepática y renal; entretanto, los fragmentos inactivos C-terminal tienen una vida media de cinco a 10 veces mayor que la hormona intacta, principalmente debido a que su depuración es exclusivamente renal [7]. Como resultado, en los pacientes normocalcémicos la paratohormona inmunorreactiva comprende [26,27]:

$\rightarrow$ Paratohormona (I-84): 5\% al 30\%

$\rightarrow$ Fragmentos C-terminal: $70 \%$ al $95 \%$

$\rightarrow$ Fragmentos $\mathrm{N}$-terminal: $4 \%$ al $8 \%$

\section{Secreción}

La secreción de la paratohormona es regulada en segundos por el calcio ionizado extracelular, lo que representa una tasa de retroalimentación negativa simple. Las señales extracelulares son percibidas por el receptor sensible al calcio (CaSR) localizado en la membrana plasmática de las células principales de la paratiroides (véase figura 3). La estimulación de este receptor lleva a la supresión de la secreción de la paratohormona por la vía de señalización intracelular del inostol trifosfato y el diacilglicerol. El receptor sensible al calcio es un receptor acoplado a proteína $G$ que se encuentra en las paratiroides, las células $C$ de la tiroides (que secretan calcitonina), el cerebro y el riñón. Las mutaciones de este receptor explican entidades como la hipercalcemia hipocalciúrica familiar, el hiperparatiroidismo neonatal severo (mutación con pérdida de función) y la hipocalcemia autosómica dominante (mutación con ganancia de función) [7].

El magnesio ionizado también influye en la secreción de la paratohormona. Los pacientes con hipocalcemia e hipomagnesemia usualmente requieren administración de magnesio para que la paratohormona sérica aumente y restablezca la calcemia. La hipomagnesemia crónica severa, como la observada en el alcoholismo, se ha asociado con la alteración en la secreción de la paratohormona, mientras que el descenso agudo del magnesio puede estimular el aumento de esta $[13,19]$.

La vitamina $D$ regula la transcripción del gen de la paratohormona y la población de células principales de la paratiroides. La 1,25-dihidroxi vitamina $D_{3}$ suprime crónicamente la síntesis de paratohormona interactuando con el receptor de vitamina D (VDR) en la glándula paratiroides [28-30]. La hiperfosfatemia también estimula la secreción de la paratohormona para promover su efecto fosfatúrico $[13,14]$. Otros elementos que modulan la secreción de la paratohormona son los cambios del $\mathrm{pH}$, el péptido relacionado con la paratohormona (PTH-rP), los estrógenos y algunas interleuquinas como la IL-I, la I-L6 y la IL-8 [7,3 I] (véase figura 3). 


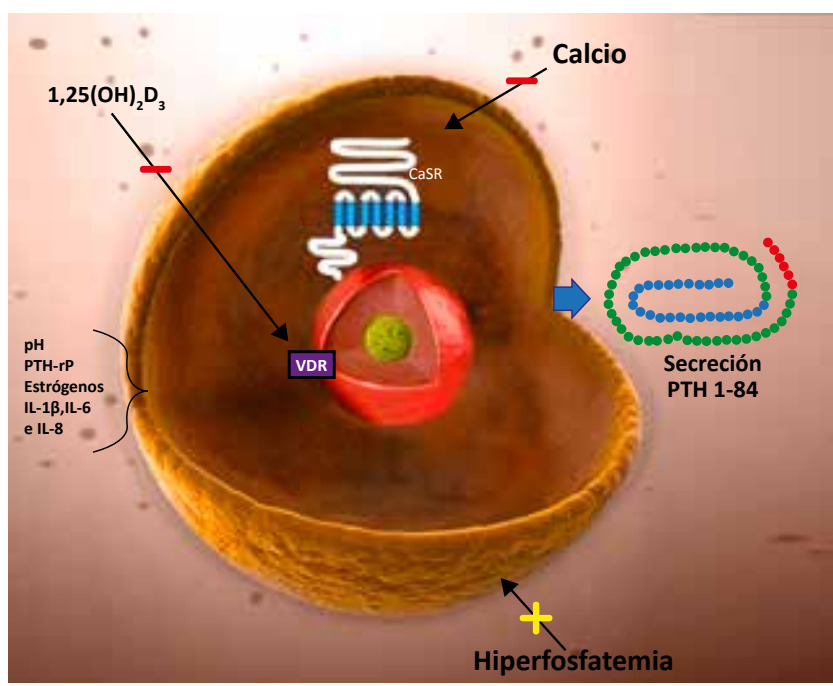

Figura 3. Fisiología de la secreción de la paratohormona, factores estimulantes e inhibitorios. $1,25(\mathrm{OH})_{2} \mathrm{D}_{3}=1,25$-dihidroxi vitamina $\mathrm{D}_{3}, \mathrm{CaSR}=$ receptor sensor de calcio, $\mathrm{PTH}-\mathrm{rP}=$ péptido relacionado con la hormona paratiroidea, $\mathrm{PTH}$ I-84= paratohormona $\mid-84$.

\section{Función}

La principal función de la paratohormona es mantener la concentración de calcio ionizado en el líquido extracelular, lo cual logra a través de los siguientes mecanismos [3,7,32]:

1. Estimulación de la resorción ósea por el osteoclasto en forma indirecta y liberación de calcio y fósforo desde el hueso (véase figura 4).

2. Estimulación de la reabsorción de calcio e inhibición de la reabsorción del fósforo en los túbulos renales.

3. Estimulación de la producción renal de la 1,25-dihidroxi vitamina D, que aumenta la absorción intestinal de calcio y fósforo.

La porción N-terminal de la paratohormona se une al receptor que modula la adenilato ciclasa y la fosfolipasa C. La mutación activadora de este receptor causa la condrodisplasia de Jansen, con hipercalcemia y desórdenes epifisiarios [34].

El efecto neto de la paratohormona es el aumento de las concentraciones de calcio y el descenso del fosfato sérico. Su efecto inmediato en el riñón consiste en aumentar el flujo plasmático y causar diuresis. En el túbulo contorneado distal causa aumento en la reabsorción del calcio y el cloro con intercambio de fosfato en la orina. Estos efectos son mediados por la activación de la adenilato ciclasa renal, que como resultado aumenta el AMPc y el fósforo urinario produciendo una acidosis hiperclorémica secundaria leve [14].

En condiciones normales, cuando la calcemia aumenta se reduce la secreción de la paratohormona, por lo tanto, se mantiene la homeostasis. Si se presenta exceso de secreción por una glándula paratiroidea autónoma con hipercalcemia asociada se excede la capacidad de reabsorción tubular del calcio y se presenta la hipercalciuria [6,7]. 

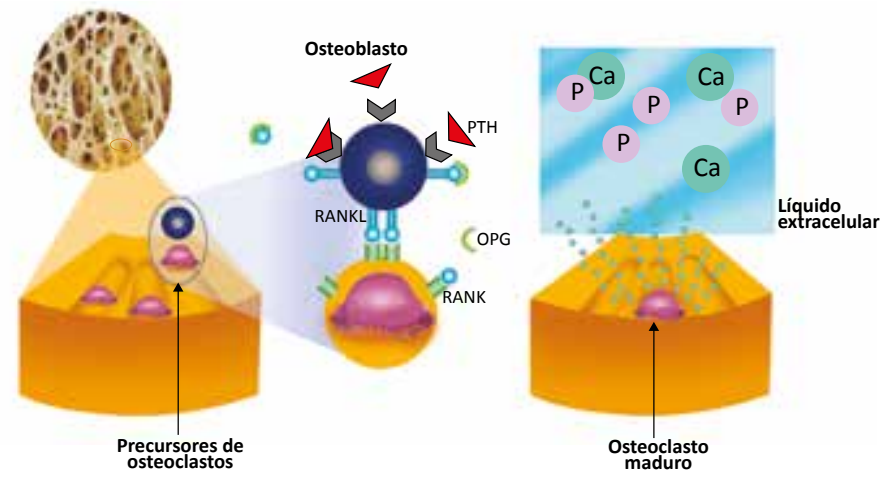

Figura 4. Fisiología de la movilización de calcio óseo mediada por la paratohormona. La paratohormona (PTH) estimula los osteoblastos para producir RANKL (ligando del receptor activador del factor nuclear $\kappa B$ ) que activa RANK (receptor activador del factor nuclear $\kappa B$ ), expresado en los precursores de osteoclastos. Esta interacción promueve la activación de los osteoclastos y prolonga su supervivencia al inhibir la apoptosis. El osteoclasto maduro realiza la resorción de la matriz extracelular, liberando calcio (Ca) y fósforo $(\mathrm{P})$ al líquido extracelular. Finalmente, la osteoprotegerina (OPG) es un receptor señuelo para RANKL que, al unirse con este ligando evita su unión con RANK, inhibiendo así la diferenciación de los precursores de osteoclastos a osteoclastos maduros y disminuyendo su supervivencia $[9,33]$.

\section{Indicaciones de la prueba de paratohormona}

Las principales indicaciones de la prueba de paratohormona incluyen [34,35]:

I. Estudio de hipercalcemia

2. Monitorización intraoperatoria de la paratohormona

3. Estudio de hipocalcemia

4. Enfermedad renal crónica

5. Estudio de enfermedad ósea metabólica

6. Estudio de nefrolitiasis

\section{Técnicas analíticas}

Históricamente los inmunoensayos para la detección de la paratohormona fueron desarrollados para reconocer la región medial y uno de los extremos, el $\mathrm{N}$-terminal o el C-terminal (véase figura 5A); sin embargo, estos métodos presentaban reacción cruzada con las secuencias de aminoácidos de los fragmentos de la paratohormona, pues medían principalmente las moléculas inactivas que se encuentran en mayor concentración que la molécula intacta (carentes del extremo aminoterminal biológicamente activo). Además, los resultados de esta prueba son difíciles de interpretar, especialmente en pacientes con alteración de la función renal en quienes se acumulan más los metabolitos inactivos $[6,36]$.

Por su parte, el método de medición de la paratohormona intacta es un ensayo inmunométrico no competitivo que utiliza dos tipos de anticuerpos dirigidos contra diferentes epítopes dentro de la molécula de paratohormona [36,38,39]. Uno de estos anticuerpos es dirigido contra la región C-terminal y captura la paratohormona I-84 circulante así como otros fragmentos. El segundo anticuerpo está dirigido contra el epítope $\mathrm{N}$-terminal y se encuentra marcado con 
radiación o quimioluminiscencia por lo que sirve para la detección (véase figura 5B) [40]. De acuerdo al sistema de detección utilizado estos ensayos pueden ser inmunoradiométricos, cuando el segundo anticuerpo está radiomarcado, e inmunoquimioluminiscentes cuando la marcación se hace con un compuesto quimioluminiscente [36,4I].

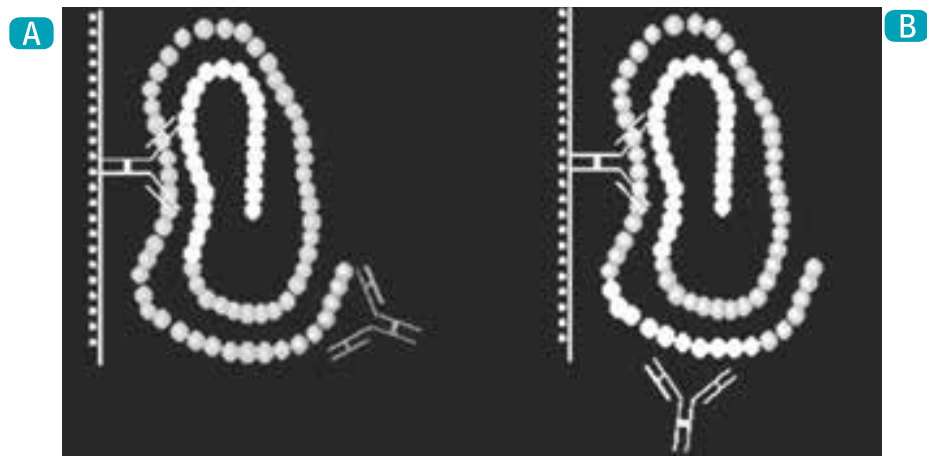

Figura 5. Immunodetección de la hormona paratiroidea por métodos de paratohormona completa (A) y paratohormona intacta de Nichols (I-84) (B). En ambas pruebas el anticuerpo inmovilizado reconoce una larga porción de la región media y C-terminal; sin embargo, en la prueba de paratohormona completa (A) el anticuerpo marcado reconoce sólo los primeros seis aminoácidos, mientras que en el método de la paratohormona intacta (B) el anticuerpo marcado reconoce un mayor número de aminoácidos de la región N-terminal. Tomado y modificado de "La Osteodistrofia Renal y la Paratohormona supresora de la remodelación ósea" por F. Cano Sch y A. Jara C, 2006, Revista Chilena de Pediatría, 77. Creative Commons 2006 por Sociedad Chilena de Pediatría [37].

La mayoría de sistemas automatizados usan pruebas inmunoquimioluminimétricas, los cuales tienen mayores ventajas que los inmunoradiométricos, como la mayor sensibilidad y especificidad por el uso de anticuerpos purificados con afinidad específica, la concentración de la prueba en rango extendido y el menor tiempo de incubación; además, no utilizan compuestos radioactivos $[6,39]$.

La primera prueba inmunométrica con doble anticuerpo (tipo sándwich) ampliamente disponible, conocida como paratohormona intacta, usaba un anticuerpo de captura dirigido contra la porción C-terminal (epítopes 39-84) y un anticuerpo de detección radiomarcado dirigido hacia los epítopes 13-34 de la porción N-terminal; por lo tanto, detectaba la paratohormona I-84 y los fragmentos largos C-terminales que carecían de los primeros dos aminoácidos de la porción N-terminal (paratohormona no I-84) [26,27,42-45].

\section{Problemas con la detección de paratohormona intacta}

Es indispensable conocer qué tipo de prueba se está utilizando y su especificidad en la detección de la paratohormona intacta debido a que la capacidad de detección de otros fragmentos puede generar valores falsamente elevados que no se corresponden con la actividad biológica de la molécula y generan confusión en el abordaje clínico, principalmente en pacientes con insuficiencia renal avanzada. Por ejemplo, en pacientes con enfermedad renal crónica, como los pacientes en hemodiálisis, los fragmentos de paratohormona no intacta (no- I-84) pueden corresponder hasta al 95\% de las moléculas inmunorreactivas en la medición de la paratohormona [45] (véase figura 6). Esta es la razón por la que se deben seleccionar los métodos analíticos con mayor precisión. 
Pacientes sin enfermedad renal crónica

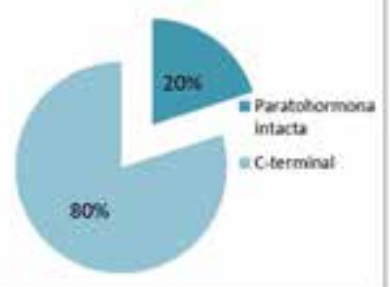

Pacientes con enfermedad renal crónica

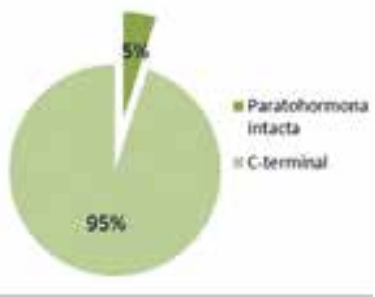

Figura 6. Paratohormona y fragmento C-terminal en pacientes con o sin enfermedad renal crónica.

Uno de los productos del clivaje de la paratohormona más predominante es el fragmento 7-84 que al parecer no se une eficientemente al receptor tipo I (PTHIR) para la hormona paratiroidea (PTH) y el péptido relacionado con la hormona paratiroidea (PTH-rP), que ejerce sus acciones a través de la unión a un receptor específico de la porción C-terminal (receptor C-PTH) [46,47]. Este receptor se detectó en los osteocitos [43], donde al parecer inhibe la resorción ósea y la liberación del calcio [46] (véase figura 7). Por lo tanto, la paratohormona 7-84 parece desempeñar un papel antagónico débil de la paratohormona y puede contribuir a la resistencia esquelética de los pacientes con enfermedad renal crónica al efecto de la paratohormona I-84 [48]. En pacientes urémicos los metabolitos de la paratohormona, incluido el 7-48, se acumulan como resultado de la disminución de la depuración renal y pueden generar resultados más altos de la molécula [17].

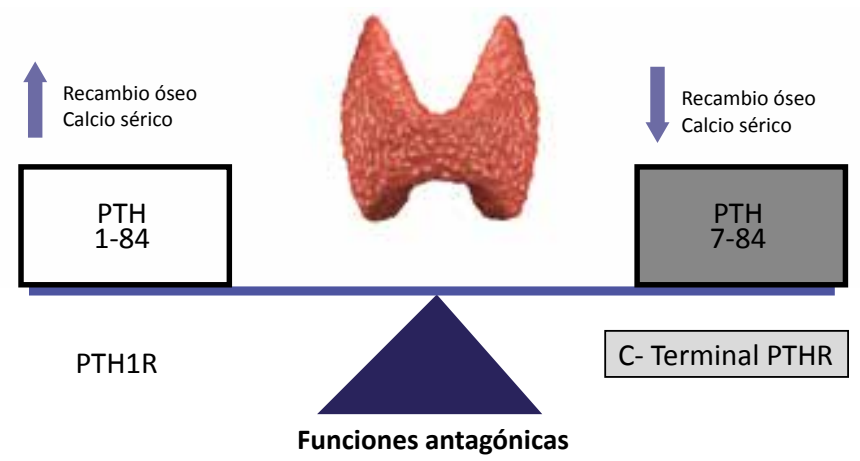

Figura 7. Funciones de la paratohormona I-84 respecto a los fragmentos C-terminales.

\section{Paratohormona biointacta}

Como ya se mencionó, las pruebas de segunda generación tradicionales, conocidas como análisis de paratohormona intacta, miden la pratohormona I-84 y otros fragmentos largos C-terminales; entretanto, las pruebas de tercera generación, definidas como análisis de paratohormona bioactiva y biointacta, detectan exclusivamente la paratohormona I-84. La medición de la paratohormona bioactiva usa anticuerpos de detección dirigidos contra epítopes en el extremo $\mathrm{N}$-terminal de la paratohormona (epítope I-4), pero al parecer también es capaz de detectar otros fragmentos $\mathrm{N}$ terminales menos prevalentes [42,49-5I]. El significado biológico de los fragmentos $\mathrm{N}$-terminales 
es incierto [26], pero se han reportado casos de hiperparatiroidismo ocasionado por secreción de estos fragmentos activos no detectados por la prueba de paratohormona intacta [52].

Los valores normales de las pruebas de tercera generación muestran variación según las estaciones, en parte, debido a las concentraciones de la 25-hidroxi vitamina $D$ durante el invierno en la población sana. Los valores normales para la prueba de paratohormona biointacta están en el rango de 8 $\mathrm{pg} / \mathrm{mL}$ a $50 \mathrm{pg} / \mathrm{mL}$ [35]. Estas pruebas eliminan la interferencia de los metabolitos, pero a pesar de su mayor especificidad, comparada con los estudios de segunda generación, es considerada de segunda línea debido a su alto costo y se usa principalmente en el seguimiento de pacientes con enfermedad metabólica ósea asociada a falla renal [5।].

Posteriormente se desarrolló la prueba con paratohormona no oxidada (actividad biológica plena) y paratohormona oxidada en dos residuos de metionina (con menor actividad biológica), en la que ambas pueden ser diferenciadas [53]. Esta prueba puede ser útil en pacientes que requieren hemodiálisis, los cuales presentan un gran porcentaje de paratohormona oxidada (entre $70 \%$ y $90 \%$ ) y menos de la activa biológicamente debido a que están sometidos a condiciones de estrés oxidativo [54]. Por otro lado, algunos datos sugieren que estos estudios pueden ser superiores en pacientes con enfermedad renal avanzada, para monitorización de la paratohormona intraoperatoria y para el diagnóstico inicial de pacientes con hiperparatiroidismo y paratohormona inapropiadamente normal cuando se mide la molécula intacta $[42,49,55]$. En un estudio, los niveles de paratohormona no oxidada fueron $10 \%$ menores que los valores cuantificados por la paratohormona intacta y al parecer estos valores de la molécula oxidada son mejores predictores de mortalidad en los pacientes en hemodiálisis [56].

\section{Tipo y toma de muestra}

La paratohormona se secreta en forma pulsátil o episódica, con un ritmo circadiano caracterizado por un pico nocturno de paratohormona intacta. Por lo tanto, la muestra se debe tomar antes de las 10 de la mañana [32]. El suero es la muestra preferida para la medición de la paratohormona. El almacenamiento prolongado del espécimen causa valores falsamente bajos [6].

\section{Intervalo de referencia}

El intervalo de referencia varía con el método empleado, la edad y sexo del paciente (véanse tablas 2 y 3) [57]. En los adultos sanos el intervalo de referencia para la paratohormona intacta es de 10 pg/mL a 65 pg/mL (ng/L) cuando se usa un método inmunométrico de doble anticuerpo [58].

\begin{tabular}{|c|c|c|c|}
\hline \multirow[t]{2}{*}{ Edad (años) } & \multicolumn{3}{|c|}{ Intervalo de referencia (ng/L) } \\
\hline & Niños & \multicolumn{2}{|c|}{ Niñas } \\
\hline $2,1-4$ & $5,7-34,2$ & \multicolumn{2}{|c|}{$3,6-32,0$} \\
\hline $4,1-6$ & $4,4-15,6$ & \multicolumn{2}{|c|}{$1,0-13,0$} \\
\hline $6,1-8$ & $2,5-27,3$ & \multicolumn{2}{|c|}{$2,7-24,6$} \\
\hline $8,1-10$ & $4,6-33,8$ & \multicolumn{2}{|c|}{$2-30,2$} \\
\hline $10,1-12$ & $2,5-25,4$ & \multicolumn{2}{|c|}{$4,3-33,9$} \\
\hline$|2|-,\mid 4$ & $1,4-25,5$ & \multicolumn{2}{|c|}{$1,6-36,5$} \\
\hline $14,1-16$ & $4,5-35,8$ & \multicolumn{2}{|c|}{ ।,2-39,0 } \\
\hline \multicolumn{4}{|c|}{$\begin{array}{l}\text { Tomada y modificada de "Serum concentrations of intact } \\
\text { parathyroid hormone in healthy children" por M Cioffi et } \\
\text { al., 2000, Clinical Chemistry, 46, p. 863. Copyright @ } 2000 \\
\text { por The American Association for Clinical Chemistry [57]. }\end{array}$} \\
\hline \multicolumn{4}{|c|}{$\begin{array}{l}\text { Tabla } 3 . \text { Valores de paratohormona intacta } \\
\text { según método de análisis }\end{array}$} \\
\hline \multicolumn{2}{|c|}{ Método } & \multirow{2}{*}{$\begin{array}{l}\mathrm{pmol} / \mathrm{L}^{*} \\
\mathrm{I}, 0-5,2\end{array}$} & $\mathrm{pg} / \mathrm{mL}$ \\
\hline \multicolumn{2}{|c|}{$\begin{array}{l}\text { Inmunoquimioluminométrico } \\
\text { (ICMA) }\end{array}$} & & $9,5-49,5$ \\
\hline \multicolumn{2}{|c|}{ Radioinmunoanálisis (RIA) } & $1,0-6,8$ & $10,0-65,0$ \\
\hline \multicolumn{2}{|c|}{$\begin{array}{l}\text { Radioinmunométrico con } \\
\text { doble anticuerpo (IRMA) }\end{array}$} & $1,0-6,0$ & $9,5-57,14$ \\
\hline \multicolumn{4}{|c|}{$\begin{array}{l}\text { *Factor de conversión para paratohormona: } p g / m L X \\
0,105=\text { pmol/L }\end{array}$} \\
\hline
\end{tabular}




\section{Factores que interfieren con el resultado de la prueba}

En las tablas 4 y 5 se presentan los principales factores analíticos y fisiológicos que disminuyen o aumentan los niveles de paratohormona, pudiendo interferir con el resultado de la prueba $[6,32,58]$.

\section{Tabla 4. Factores que disminuyen la paratohormona}

\section{Analíticos}

Retraso en la congelación del suero por dos a cuatro horas (pérdida 4\%-8\%) [4I]

Retraso en la separación de las células (pérdida 6\%)

Dilución por anticoagulantes líquidos

Recolección de muestras en tubos con separador de suero

La concentración en suero disminuye $15 \%$ en tres horas a $25^{\circ} \mathrm{C}$

\section{Fisiológicos}

Ingestión de alcohol: disminución del 42\% con ingesta de 1,2 a I,5 g/kg de peso por tres horas [59,60]

Alcoholismo crónico [60]

Menor concentración en neonatos con lactancia materna [6I]

Ingestión o suministro venoso de suplementos de calcio (55\%-73\%) [3।]

Hemodiálisis: reducción del 30\% inmediatamente después de la hemodiálisis. Sin cambios por diálisis peritoneal

Calcitriol: después de tratamiento por cuatro días con $3 \mu \mathrm{g} /$ día

Inmovilización

Embarazo

Estaciones: menor concentración en verano, nadir de junio a agosto

Pérdida marcada de peso (>35 kg reducción del 25\%)

\section{Tabla 5. Factores que aumentan la paratohormona}

\section{Analíticos}

Anticuerpos heterófilos que ocurren naturalmente [62]

Factor reumatoide positivo [62]

\section{Fisiológicos}

Enfermedad aguda: pacientes críticamente enfermos

Envejecimiento: aumenta desde los 20 hasta los 90 años (38\% en hombres y 35\% en mujeres)

Alcoholismo crónico con disfunción hepática [59]

Variación diurna: concentración se eleva en la tarde, máxima a las 3 am y se normaliza a las 8 am

Infusión de dopamina

EDTA [3।]

Ejercicio extenuante, se normaliza una hora después

Ayuno prolongado (96 horas)

Carga oral de glucosa

Menopausia

Obesidad

Carga oral de fosfato (aumenta I25\%, una hora después de administrar I g de fosfato)

Lactancia [6I]

Embarazo: aumento progresivo en cada trimestre

Raza negra

Estaciones: zenit de octubre a marzo

Vegetarianismo 


\section{Paratohormona intraoperatoria}

Históricamente, la cirugía de paratiroides consistía en la exploración bilateral del cuello con el objetivo de identificar las glándulas aumentadas de tamaño. En años recientes este procedimiento, costoso e invasivo, se ha reemplazado por la paratiroidectomía mínimamente invasiva, previa localización del adenoma con estudios de imagen o medicina nuclear. Este abordaje ha reducido los costos quirúrgicos y el tiempo de hospitalización postquirúrgica [63]. En caso de hiperplasia paratiroidea o sospecha de enfermedad multiglandular se requiere siempre exploración bilateral del cuello $[6,64]$.

Antes de la cirugía se obtiene una medición basal de la paratohormona; una vez se identifica y reseca el adenoma paratiroideo, el cirujano espera 10 a 20 minutos y obtiene una segunda muestra para evaluar la paratohormona posresección. Esta paratohormona intraoperatoria debe disminuir entre el $50 \%$ y el $75 \%$ del valor prequirúrgico o debe presentar una tendencia significativa al descenso en pacientes con paratohormona prequirúrgica muy elevada. Este descenso sugiere que el tejido adenomatoso fue removido; si no ocurre la disminución esperada en los niveles de paratohormona el cirujano debe realizar una exploración exhaustiva en busca de un adenoma adicional, múltiples adenomas o hiperplasia, según el proceso subyacente [21,64,65].

Además, se recomienda la medición de la paratohormona intraoperatoria en pacientes con hiperparatiroidismo primario y en aquellos que requieren reintervención por persistencia o recurrencia del hiperparatiroidismo [65].

\section{Técnicas analíticas}

La técnica intraoperatoria para medir la paratohormona intacta requiere sangre recolectada en un tubo con EDTA (plasma) o un tubo tapa roja (suero). La muestra se debe mantener a temperatura fría para minimizar la fragmentación y procesar rápidamente para la determinación de la paratohormona. Este ensayo inmunoquimioluminimétrico provee resultados rápidos al modificar algunos parámetros de la prueba estándar; específicamente, acelera la reacción antígeno-anticuerpo, aumenta la temperatura de incubación y requiere de agitación constante y cambios en los volúmenes de la muestra y el reactivo. Estos resultados rápidos, a pesar de ser más costosos y menos sensibles y precisos, tienen una adecuada correlación con la prueba estándar y son aceptables para evaluar los descensos significativos en la concentración de la paratohormona durante la cirugía $[6,63,65]$.

\section{Variabilidad de la prueba}

Existe una variabilidad biológica inherente en los niveles de paratohormona debido a los cambios en la ingesta de calcio y la función renal. Además, no existe un método de referencia para medir la paratohormona y los diferentes tipos de pruebas no comparten un estándar sintético o recombinante de la paratohormona. En consecuencia, los valores pueden variar aun al usar pruebas de la misma generación de diferentes empresas manufactureras [40,66]. Esta variabilidad es fundamental para entender que se deben definir rangos de normalidad específicas de cada tipo de prueba y de la población estudiada (comunidad general, pacientes con enfermedad renal crónica, entre otros). Idealmente las decisiones se deben tomar con base en las tendencias más que en los valores aislados y los pacientes se deben monitorizar en el mismo laboratorio o con pruebas de la misma marca de fabricación [58,62,67]. 
Por su parte, los ensayos inmunométricos son vulnerables a la interferencia por anticuerpos heterófilos que pueden estar presentes hasta en el $11 \%$ de la población. Estos anticuerpos pueden actuar como puentes entre los anticuerpos de captura y detección de la prueba, ocasionando resultados falsamente positivos. Además, estos anticuerpos heterófilos están aumentando en prevalencia debido al incremento en el uso de anticuerpos monoclonales en el tratamiento de enfermedades inflamatorias, el cáncer y en trasplantes [68].

\section{Péptido relacionado con la paratohormona Fisiología}

El péptido relacionado con la paratohormona (PTH-rP) se describió inicialmente en tumores derivados del pulmón, la mama, el riñón y otros órganos sólidos. Actualmente, se reconoce como una hormona con funciones paracrinas y autocrinas. El PTH-rP se compone de 14| aminoácidos con una homología significativa con la paratohormona en los primeros 13 y es el producto de un gen en el cromosoma 12 singénico con el gen de la paratohormona en el cromosoma II. Este péptido activa el mismo receptor de la paratohormona y ejerce los mismos efectos biológicos en el hueso, el riñón y el intestino, siendo su efecto neto aumentar las concentraciones séricas de calcio [25].

El PTH-rP es producido aproximadamente por el 50\% de los cánceres de mama y parece ser estimulado por factores derivados del tejido óseo como el factor transformante de crecimiento- $\beta$ (TGF- $\beta$ ) [69]. Este péptido es el responsable de la hipercalcemia humoral en pacientes con enfermedades malignas. Además, se ha descrito elevación del PTH-rP en el 50\% al $90 \%$ de los pacientes con hipercalcemia asociada a malignidad, principalmente en pacientes con cáncer escamocelular de pulmón, esófago, cérvix y de la piel. Los niveles de PTH-rP son normales en pacientes con hipercalcemia no relacionada con malignidad, enfermedad renal crónica o hipoparatiroidismo [6,25].

Finalmente, algunas hiperplasias benignas, incluyendo la hipertrofia mamaria masiva, los cambios mamarios durante la lactancia, los tumores secretores de péptido intestinal vasoactivo y los feocromocitomas pueden elaborar este péptido [6].

\section{Técnica analítica e intervalo de referencia}

El PTH-rP se mide por ensayo inmunométrico (usualmente inmunoradiométrico), en el que diferentes anticuerpos contra secuencias del PTH-rP son usados como anticuerpos de captura y anticuerpos radiomarcados. El límite de detección de estos ensayos se describió entre 0,1 pmol/L a I,0 pmol/L [3]. El intervalo de referencia para el PTH-rP es dependiente del método, pero se acepta que puede ser desde indetectable hasta valores alrededor de 2 pmol/L. Los valores en pacientes con hipercalcemia asociada a malignidad aumentan más de 10 veces el valor normal [25].

\section{Calcitonina}

\section{Síntesis y metabolismo}

La calcitonina es sintetizada y secretada por las células C (células parafoliculares) de la glándula tiroides y actúa en los huesos, los riñones y el tracto gastrointestinal. La calcitonina circulante 
inmunorreactiva se deriva de un precursor más grande y la forma monomérica es la única biológicamente activa. El monómero de calcitonina es un péptido de 32 aminoácidos con una masa molecular de 3.500 Da. El aumento en la concentración de calcio ionizado es el estímulo más importante para la secreción de calcitonina. Otros secretagogos de la calcitonina incluyen algunos péptidos gastrointestinales, en particular la gastrina, lo que puede explicar la ligera elevación postprandial de la calcitonina [70].

El receptor de la calcitonina es estructuralmente similar al receptor tipo I (PTHIR) para la hormona paratiroidea (PTH) y el péptido relacionado con la hormona paratiroidea (PTH-rP) y al receptor de secretina. Este receptor tiene varias isoformas y su expresión es influenciada por las concentraciones de calcitonina [7l]. La calcitonina es metabolizada a los pocos minutos de su secreción, principalmente en los riñones [6,7].

\section{Función y uso clínico}

El efecto de la calcitonina es el descenso de las concentraciones de calcio y fósforo, pero su papel fisiológico aún no es claro. La calcitonina se une directamente al osteoclasto e inhibe la resorción ósea. Esta inhibición ocurre en minutos y, aunque es transitoria y de poca magnitud en la homeostasis global del calcio, puede ser importante en el control a corto plazo cuando se reciben cargas de calcio. Además, la calcitonina inhibe la acción de la paratohormona y la vitamina $D$, y en el riñón causa aumento en la depuración del calcio y el fósforo [72] (véase figura I).

La utilidad clínica de la medición de la calcitonina no se trata del estudio del metabolismo óseo y fosfocálcico, sino que radica en el diagnóstico y seguimiento del cáncer medular de tiroides [6,72].

\section{Técnicas analíticas e intervalos de referencia}

En el pasado la medición de la calcitonina se realizaba por radioinmunoensayo; sin embargo, la heterogeneidad de la calcitonina circulante y las diferencias en el desempeño de los reactivos y los insumos generaron resultados contradictorios en los valores de referencia. Actualmente se dispone de métodos inmunométricos con doble sitio de unión y (electroinmunoensayo y ensayo inmunoradiométrico) de alta sensibilidad (límite de detección tan bajo como 2 pg/mL) para la medición de la calcitonina [6,72].

El intervalo de referencia para la calcitonina sérica en adultos sanos es menor de $25 \mathrm{pg} / \mathrm{mL}$ para hombres y menor de $20 \mathrm{pg} / \mathrm{mL}$ para mujeres. Los niveles de calcitonina se afectan por el género, la edad, la etapa del crecimiento, el embarazo, la lactancia y la ingesta alimentaria [6].

\section{Vitamina $D$ y sus metabolitos}

\section{Síntesis y metabolismo}

La hormona esteroidea 1,25-dihidroxi vitamina D es el metabolito con mayor actividad biológica de la familia de la vitamina D. El precursor de la vitamina $D$, conocido como colecalciferol o vitamina $\mathrm{D}_{3}$ puede ser ingerido en la dieta o sintetizado en la piel por exposición a la luz solar a partir del 7-dehidrocolesterol (provitamina D). La vitamina D derivada de las plantas se denomina vitamina $D_{2}$ o ergosterol. Estas formas de vitamina $D$ deben ser metabolizadas a formas activas de la hormona, cuyo proceso de activación ocurre en dos pasos: el primero se lleva a cabo en el hígado y el segundo en el riñón [29]. 
La vitamina $D_{3}$ es transportada al hígado, unida a la globulina $\alpha$-I específica. En el hígado, la vitamina $D_{3}$ sufre la primera hidroxilación para producir la 25-hidroxi vitamina $D$ (calcidiol), cuyas concentraciones reflejan la cantidad de vitamina $\mathrm{D}$ ingerida y sintetizada por la piel. La 25-hidroxi vitamina $D$ se une a la proteína transportadora de vitamina $D$ y es llevada al riñón, donde ocurre la segunda hidroxilación por la la-hidroxilasa en las mitocondrias del túbulo proximal para formar el metabolito más potente, la I,25-dihidroxi vitamina D (calcitriol) $[6,73]$.

La hidroxilación renal de la 25-hidroxi vitamina D es el principal sitio de control del metabolismo de la vitamina $D$ y es regulado por las concentraciones de fósforo, calcio y paratohormona. El estímulo más potente para la inducción de la actividad de la I $\alpha$-hidroxilasa renal es la paratohormona; en forma independiente, la deficiencia de fósforo también estimula la producción de calcitriol. Las concentraciones de calcio intervienen de forma indirecta a través de la paratohormona [29,30].

Otros sitios extrarrenales conocidos con producción significativa de la I,25-dihidroxi vitamina $D$ son la placenta y el tejido granulomatoso. La vida media de la 1,25-dihidroxi vitamina $D$ en la circulación es de aproximadamente 5 horas y su excreción es por vía urinaria y por metabolitos fecales [7].

Otros metabolitos de la vitamina $\mathrm{D}$ son producidos en el riñón, la mayoría de ellos biológicamente inertes. El metabolito más notable es el 24,25-dihidroxi vitamina $D_{3}$, producido por la acción de la $24 \alpha$-hidroxilasa renal en respuesta a la elevación del fosfato inorgánico o cuando los niveles de paratohormona se encuentran bajos [6,29].

\section{Función}

La I,25-dihidroxi vitamina D, unida a la proteína transportadora de vitamina D, es llevada al intestino, donde es captada libremente por las células y llevada hasta el receptor nuclear específico. Aunque este receptor puede unir otras formas de vitamina D, la afinidad por la 1,25-dihidroxivitamina $D$ es 1.000 veces superior a la de la 25 -hidroxivitamina D. Como resultado de la interacción de la I,25 hidroxivitamina D con el receptor se promueve la síntesis de la proteína ligadora de calcio y al estimular la expresión de proteínas transportadoras de calcio el efecto neto es el transporte de calcio y fósforo desde el lumen del intestino delgado a la circulación. En cuanto al riñón se potencia la acción de la paratohormona para aumentar la reabsorción tubular de calcio y en el hueso se estimula la producción de osteocalcina, osteopontina y fosfatasa alcalina $[6,7,29,30]$.

Además, la 1,25-dihidroxi vitamina $D$ es un potente agente de diferenciación de los precursores del osteoclasto, causando su maduración y formación de células multinucleadas capacitadas para la resorción ósea; de esta forma, moviliza el calcio y el fósforo para que estén disponibles en la mineralización ósea [7].

Otras evidencias sugieren que la vitamina $D$ tiene muchísimas otras propiedades que se extienden más allá de su efecto calciotrópico. La vitamina D puede ser una hormona del desarrollo, con propiedades inmunomoduladoras y antitumorales, entre otras funciones $[6,7,29,30]$.

\section{Técnicas analíticas}

Existen más de 35 metabolitos de la vitamina $D$, pero las mediciones clínicamente relevantes son las de las concentraciones de la 25-hidroxi vitamina D y la I,25-dihidroxi vitamina D. Es- 
pecíficamente, la 25-hidroxi vitamina $D$ es considerada un mejor marcador del estatus de la vitamina $\mathrm{D}$ debido a que su vida media es más prolongada que la de la 1,25-dihidroxi vitamina D (dos a tres semanas frente a cinco a ocho horas) [74]; además, presenta menor fluctuación relacionada con la ingesta y la exposición solar, se encuentra en mayor concentración y presenta mayor facilidad en la medición. Por su parte, la medición de la 1,25-dihidroxi vitamina D es útil en el diagnóstico diferencial de algunas condiciones que generan hipercalcemia, hipercaliciuria e hipocalcemia, y en alteraciones óseas y del metabolismo mineral $[6,29]$.

Debido a que la vitamina $\mathrm{D}_{2}$ y la vitamina $\mathrm{D}_{3}$ son metabolizadas a compuestos biológicamente similares, para propósitos clínicos las pruebas deben medir la 25-hidroxi vitamina $D_{2}$ y la 25-hidroxi vitamina $D_{3}$ o la 1,25-dihidroxi vitamina $D_{2}$ y la 1,25-dihidroxi vitamina $D_{3}$. En la actualidad, el método de referencia para la medición de la 25-hidroxi vitamina $D$ es la espectrometría de masas dual. Otros ensayos para los metabolitos de la vitamina $D$ incluyen el radioinmunoanálisis (RIA) y la inmunoquimioluminiscencia [75].

\section{Intervalos de referencia}

El intervalo de referencia para la 25-hidroxi vitamina $D$ en suero es aproximadamente $10 \mathrm{ng} / \mathrm{mL}$ a $50 \mathrm{ng} / \mathrm{mL}(25 \mathrm{nmol} / \mathrm{L}$ a $125 \mathrm{nmol} / \mathrm{L})$ y para la 1,25-dihidroxi vitamina entre I $5 \mathrm{pg} / \mathrm{mL}$ y $60 \mathrm{pg} / \mathrm{mL}$ (36 pmol/L a $144 \mathrm{pmol} / \mathrm{L}$ ) [3]. Los niveles de 25-hidroxi vitamina D están influenciados por la exposición solar, la latitud, la pigmentación de la piel, el uso de protección solar y la función hepática. Los niveles de 25-hidroxi vitamina D también presentan variación con las estaciones del año, siendo las concentraciones en invierno del $40 \%$ al 50\% menor respecto al verano relacionado con la menor exposición a la radiación UV. Las concentraciones de vitamina D pueden variar con la edad y aumentan durante la gestación [28-30,76,77].

\section{Fosfatoninas}

Las fosfatoninas representan un grupo de factores reguladores del fosfato de los que aún se tiene un conocimiento incompleto. Estos factores incluyen el FGF-23, la MEPE y la proteína secretada relacionada con Frizzled-4 (sFRP4; del inglés, secreted Frizzled Related Protein-4), los cuales actúan reduciendo la reabsorción renal del fósforo inorgánico de forma directa, por su acción sobre los túbulos renales, e indirecta, a través de la inhibición de la l $\alpha$-hidroxilasa, causando disminución en la síntesis de 1,25-dihidroxivitamina D y, por tanto, de la absorción del calcio y el fósforo [16,78]. Específicamente, se ha descrito que el FGF-23 produce un aumento en la excreción del fosfato y disminución de la acción de la I $\alpha$-hidroxilasa, aumentando la actividad de la 24-hidroxilasa que convierte la vitamina $D$ en un metabolito inactivo, lo que afecta la absorción del calcio y el fósforo como ya se describió. La paratohormona aumenta la producción del FGF-23 y este, por su parte, hace una retroalimentación negativa inhibiendo la secreción de la paratohormona [79] (véase figura 8).

Tanto los mecanismos de acción directos como indirectos de las fosfatoninas producen disminución de los niveles de fosfato, lo que ocasiona raquitismo en los niños y osteomalacia en los adultos. Además, los niveles elevados de las fosfatoninas se han relacionado con la osteomalacia oncogénica, el raquitismo hipofosfatémico ligado al $X$ y el raquitismo hipofosfatémico autosómico dominante [80-83]. 


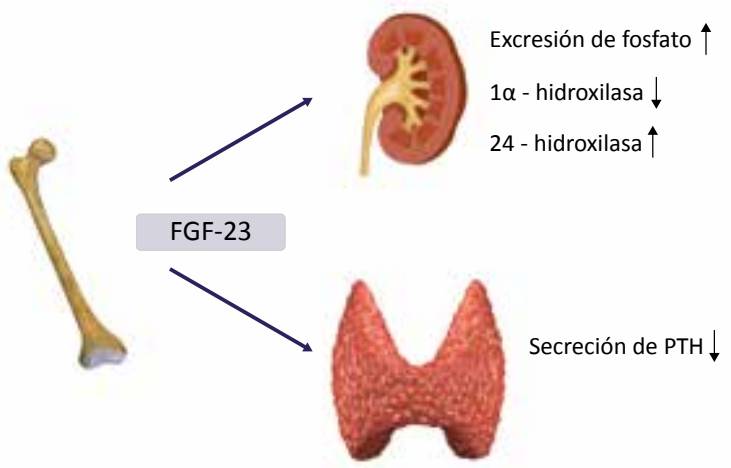

Figura 8. FGF-23 y sus posibles mecanismos de acción en la disminución de la absorción de calcio y fósforo.

Las mutaciones en el gen PHEX (del inglés, phosphate regulating endopeptidase homolog, $X$ linked), el cual codifica para una endopeptidasa dependiente de zinc tipo II que se cree participa en la mineralización ósea y la reabsorción renal del fosfato, se han descrito en el raquitismo hipofosfatémico ligado al X, mientras que las mutaciones activadoras en el FGF-23 se han encontrado en el raquitismo hipofosfatémico autosómico dominante [78,83,84]. Todas estas entidades clínicas se caracterizan por hipofosfatemia, aumento de la fosfaturia y alteraciones en la mineralización ósea, usualmente en presencia de calcemia normal. Por otro lado, las mutaciones que disminuyen la acción del FGF-23 producen enfermedades que se caracterizan por reducción de la fosfaturia y calcinosis hiperfosfatémica [82,85].

\section{Técnicas analíticas}

Estos factores de crecimiento han sido evaluados en forma experimental mediante la reacción en cadena de la polimerasa (PCR; del inglés, Polymerase Chain Reaction) y el ensayo inmunosorbente ligado a enzimas para el FGF-23 intacto y los fragmentos procesados ( 8 KDa y 12 KDa). Además, se ha utilizado la PCR transcriptasa reversa (RT-PCR) con muestras tisulares de tumores mesenquimales con fosfaturia [86]. Recientemente, se desarrolló una prueba comercial enzimática con inmunometría tipo sándwich [16,8|,86,87].

Los resultados de los niveles de fosfatoninas se deben analizar en el contexto de las concentraciones de calcio, fósforo, magnesio, paratohormona, 25-hidroxi vitamina y 1,25-dihidroxi vitamina [8I]. Por ejemplo, se debe sospechar osteomalacia tumoral en pacientes con calcio sérico, paratohormona y magnesio sérico normales, pero con hipofosfatemia persistente (en ocasiones severa) y aumento del fósforo y magnesio urinarios. En este escenario la 1,25-dihidroxi vitamina $D$ se debe encontrar baja o en el límite inferior, mientras que la 25-hidroxi vitamina D se puede encontrar normal. En estos casos, la medición del FGF-23 puede ayudar a diagnosticar una osteomalacia oncogénica [7I].

La medición del FGF-23 puede asistir en el seguimiento de pacientes que fueron sometidos a tratamiento quirúrgico de la lesión neoplásica. Además, dado que su vida media es muy corta, requiriendo un recambio rápido, se ha propuesto como un candidato para la detección y localización de tumores pequeños u ocultos a través de la cateterización venosa y la toma selectiva de muestras $[6,15,86,87]$. 


\section{Intervalo de referencia}

Los valores de FGF-23 pueden estar marcadamente elevados (> $900 \mathrm{RU} / \mathrm{mL}$ ) en niños menores de tres meses de edad, y a partir de entonces y hasta los 17 años se reducen a menos de 230 $\mathrm{RU} / \mathrm{mL}$. En los adultos mayores de 18 años se ha definido un límite superior de $189 \mathrm{RU} / \mathrm{mL}$ [6].

En pacientes con osteomalacia oncogénica los valores están elevados por lo menos dos veces el límite superior, por lo que se considera de utilidad diagnóstica en este contexto. En pacientes con enfermedad renal crónica se ha usado la medición del FGF-23 como predictor del desarrollo de hiperparatiroidismo secundario y desenlaces adversos, pero las pruebas tienen variaciones y dificultades en la definición de puntos de corte reproducibles [87].

\section{Conclusiones}

En la aproximación clínica de los pacientes con alteraciones de la homeostasis mineral ósea es indispensable entender la fisiología de las hormonas responsables de preservar la salud ósea y de mantener la disponibilidad de calcio, fósforo y magnesio necesarios para múltiples funciones biológicas.

En la actualidad están disponibles métodos sensibles y precisos para la medición de estas moléculas involucradas en el metabolismo fosfocálcico; sin embargo, para la interpretación cuidadosa de los resultados se deben tener en cuenta las variables de confusión inherentes a las condiciones clínicas del paciente y las características metodológicas de cada prueba. Los intervalos de referencia se deben definir con base en un método específico, aplicado a una población específica y analizarse siempre en el contexto clínico del paciente y en correlación con otros resultados bioquímicos.

\section{Agradecimientos}

Agradecemos al Dr. Germán Campuzano Maya y a la Editora Médica Colombiana S.A. (EDIMECO S.A.) por la colaboración con la revisión y edición de este artículo y por sus esfuerzos para promover las publicaciones científicas del personal de la salud de nuestro país.

\section{Bibliografía}

I. Boden SD, Kaplan FS. Calcium homeostasis. Orthop Clin North Am 1990; 21 : 31 -42.

2. Watts NB. Clinical utility of biochemical markers of bone remodeling. Clin Chem 1999; 45: I359- 1368.

3. Endres DB, Rude RK. Mineral and Bone Metabolism. En: Burtis CA, Ashwood ER, eds. Tietz Textbook of Clinical Chemistry (ed 3ra). Filadelfia, Estados Unidos: Saunders; 1999: 1395- 1457.

4. Calvo MS, Eyre DR, Gundberg CM. Molecular basis and clinical application of biological markers of bone turnover. Endocr Rev 1996; 17: 333-368.

5. Plotkin LI, Bellido T. Osteocytic signalling pathways as therapeutic targets for bone fragility. Nat Rev Endocrinol 2016; May 27 [Epub ahead of print].

6. Richard M, Matthew P. Henry's Clinical Diagnosis and Management by Laboratory Methods (ed 23a): Elsevier; 2016.

7. Mundy GR, Guise TA. Hormonal control of calcium homeostasis. Clin Chem 1999; 45: I347-I 352.

8. Carafoli E. Intracellular calcium homeostasis. Annu Rev Biochem 1987; 56: 395-433.

9. Hsu H, Lacey DL, Dunstan CR, Solovyev I, Colombero A, Timms E, et al. Tumor necrosis factor receptor family member RANK mediates osteoclast 
differentiation and activation induced by osteoprotegerin ligand. Proc Natl Acad Sci U S A 1999; 96: 3540-3545.

10. Payne RB, Little AJ, Williams RB, Milner JR. Interpretation of serum calcium in patients with abnormal serum proteins. Br Med J 1973; 4: 643-646.

I1. Hristova EN, Cecco S, Niemela JE, Rehak NN, Elin RJ. Analyzer-dependent differences in results for ionized calcium, ionized magnesium, sodium, and $\mathrm{pH}$. Clin Chem 1995; 4I: 1649-1653.

12. Wang S, McDonnell EH, Sedor FA, Toffaletti JG. $\mathrm{pH}$ effects on measurements of ionized calcium and ionized magnesium in blood. Arch Pathol Lab Med 2002; 126: 947-950.

13. Weisinger JR, Bellorin-Font E. Magnesium and phosphorus. Lancet 1998; 352: 39|-396.

14. Bellorin-Font E, Starosta R, Milanes CL, Lopez C, Pernalete N, Weisinger J, et al. Effect of acidosis on PTH-dependent renal adenylate cyclase in phosphorus deprivation: role of $\mathrm{G}$ proteins. Am J Physiol 1990; 258: FI640-1649.

15. Liu S, Quarles LD. How fibroblast growth factor 23 works. J Am Soc Nephrol 2007; I8: 1637-I647.

16. Quarles LD. FGF23, PHEX, and MEPE regulation of phosphate homeostasis and skeletal mineralization. Am J Physiol Endocrinol Metab 2003; 285: EI-9.

17. Quarles LD. Role of FGF23 in vitamin D and phosphate metabolism: implications in chronic kidney disease. Exp Cell Res 2012; 31 8: 1040- 1048.

18. Daly JA, Ertingshausen G. Direct method for determining inorganic phosphate in serum with the «CentrifiChem». Clin Chem 1972; I 8: 263-265.

19. Elin RJ. Magnesium metabolism in health and disease. Dis Mon 1988; 34: 161-218.

20. Quamme GA. Control of magnesium transport in the thick ascending limb. Am J Physiol 1989; 256: FI97-210

21. Quamme GA. Renal magnesium handling: new insights in understanding old problems. Kidney Int 1997; 52: I|80-। 195.

22. Papazachariou IM, Martinez-Isla A, Efthimiou E, Williamson RC, Girgis SI. Magnesium deficiency in patients with chronic pancreatitis identified by an intravenous loading test. Clin Chim Acta 2000; 302: |45- 154.

23. Huijgen HJ, Sanders R, Cecco SA, Rehak NN, Sanders GT, Elin RJ. Serum ionized magnesium: comparison of results obtained with three ion-selective analyzers. Clin Chem Lab Med 1999; 37: 465-470.

24. Cecco SA, Hristova EN, Rehak NN, Elin RJ. Clinically important intermethod differences for physiologically abnormal ionized magnesium results. Am J Clin Pathol 1997; 108: 564-569.

25. Fritchie K, Zedek D, Grenache DG. The clinical utility of parathyroid hormone-related peptide in the assessment of hypercalcemia. Clin Chim Acta 2009; 402: | 46-149.

26. D'Amour P, Brossard JH, Rousseau L, Roy L, Gao $\mathrm{P}$, Cantor T. Amino-terminal form of parathyroid hormone $(\mathrm{PTH})$ with immunologic similarities to $\mathrm{hPTH}(\mathrm{I}-84)$ is overproduced in primary and secondary hyperparathyroidism. Clin Chem 2003; 49: 2037-2044.

27. D'Amour P, Brossard JH, Rakel A, Rousseau L, Albert C, Cantor T. Evidence that the amino-terminal composition of non-( I-84) parathyroid hormone fragments starts before position 19. Clin Chem 2005; 51: 169-176.

28. Sempos CT, Vesper HW, Phinney KW, Thienpont LM, Coates PM. Vitamin D status as an international issue: national surveys and the problem of standardization. Scand J Clin Lab Invest Suppl 20 I2; 243: 32-40.

29. Holick MF. Vitamin D deficiency. N Engl J Med 2007; 357: 266-28I.

30. Vieth $R$. What is the optimal vitamin $D$ status for health? Prog Biophys Mol Biol 2006; 92: 26-32.

31. Lips P, Netelenbos JC, van Doorn L, Hackeng WH, Lips C]. Stimulation and suppression of intact parathyroid hormone (PTHI-84) in normal subjects and hyperparathyroid patients. Clin Endocrinol (Oxf) 199।; 35: 35-40.

32. Jubiz W, Canterbury JM, Reiss E, Tyler FH. Circadian rhythm in serum parathyroid hormone concentration in human subjects: correlation with serum calcium, phosphate, albumin, and growth hormone levels. J Clin Invest 1972; 5 I: 2040-2046.

33. Honma M, Ikebuchi Y, Kariya Y, Suzuki H. Regulatory mechanisms of RANKL presentation to osteoclast precursors. Curr Osteoporos Rep 2014; 12: II5-120.

34. Bastepe M, Raas-Rothschild A, Silver J, Weissman I, Wientroub S, Juppner $\mathrm{H}$, et al. A form of Jansen's metaphyseal chondrodysplasia with limited metabolic and skeletal abnormalities is caused by a novel activating parathyroid hormone (PTH)/PTH-related peptide receptor mutation. J Clin Endocrinol Metab 2004; 89: 3595-3600.

35. Nichols Advantage. BIO-INTACT PTH assay directional insert. ADS Document 7040. 2004.

36. Goodman WG, Juppner H, Salusky IB, Sherrard DJ. Parathyroid hormone (PTH), PTH-derived peptides, and new PTH assays in renal osteodystrophy. Kidney Int 2003; 63: I-II.

37. Cano Sch F, Jara C A. La Osteodistrofia Renal y la Paratohormona supresora de la remodelación ósea. Rev Chil Pediatr 2006; 77: 127- 137.

38. Nussbaum SR, Zahradnik RJ, Lavigne JR, Brennan GL, Nozawa-Ung K, Kim LY, et al. Highly sensitive two-site immunoradiometric assay of parathyrin, and its clinical utility in evaluating patients with hy- 
percalcemia. Clin Chem 1987; 33: I364- 1367.

39. Martin KJ, Akhtar I, Gonzalez EA. Parathyroid hormone: new assays, new receptors. Semin Nephrol 2004; 24: 3-9.

40. Hecking M, Kainz A, Bielesz B, Plischke M, Beilhack $\mathrm{G}$, Horl WH, et al. Clinical evaluation of two novel biointact PTH(I-84) assays in hemodialysis patients. Clin Biochem 20 I2; 45: I645-I65I.

41. Wood PJ. The measurement of parathyroid hormone. Ann Clin Biochem 1992; 29 ( Pt I): II-2I.

42. John MR, Goodman WG, Gao P, Cantor TL, Salusky IB, Juppner H. A novel immunoradiometric assay detects full-length human PTH but not amino-terminally truncated fragments: implications for PTH measurements in renal failure. I Clin Endocrinol Metab 1999; 84: 4287-4290.

43. Brossard JH, Cloutier M, Roy L, Lepage R, Gascon-Barre M, D'Amour P. Accumulation of a non( I-84) molecular form of parathyroid hormone (PTH) detected by intact PTH assay in renal failure: importance in the interpretation of PTH values. J Clin Endocrinol Metab 1996; 81: 3923-3929.

44. Lepage R, Roy L, Brossard JH, Rousseau L, Dorais C, Lazure C, et al. A non-( -84$)$ circulating parathyroid hormone (PTH) fragment interferes significantly with intact PTH commercial assay measurements in uremic samples. Clin Chem 1998; 44: 805-809.

45. Brossard JH, Lepage R, Cardinal H, Roy L, Rousseau L, Dorais C, et al. Influence of glomerular filtration rate on non-( 1 -84) parathyroid hormone (PTH) detected by intact PTH assays. Clin Chem 2000; 46: 697-703.

46. Divieti P, John MR, Juppner H, Bringhurst FR. Human $\mathrm{PTH}-(7-84)$ inhibits bone resorption in vitro via actions independent of the type I PTH/PTHrP receptor. Endocrinology 2002; 143: 17|- 176.

47. Nguyen-Yamamoto L, Rousseau L, Brossard JH, Lepage R, D'Amour P. Synthetic carboxyl-terminal fragments of parathyroid hormone (PTH) decrease ionized calcium concentration in rats by acting on a receptor different from the PTH/PTH-related peptide receptor. Endocrinology 200 I; |42: 13861392.

48. Wesseling-Perry K, Harkins GC, Wang HJ, Elashoff R, Gales B, Horwitz MJ, et al. The calcemic response to continuous parathyroid hormone $(\mathrm{PTH})(\mathrm{I}-34)$ infusion in end-stage kidney disease varies according to bone turnover: a potential role for PTH(7-84). J Clin Endocrinol Metab 2010; 95: 2772-2780.

49. Gao P, Scheibel S, D'Amour P, John MR, Rao SD, Schmidt-Gayk H, et al. Development of a novel immunoradiometric assay exclusively for biologically active whole parathyroid hormone I-84: implications for improvement of accurate assessment of parathyroid function. J Bone Miner Res 2001; 16: 605-6I4.
50. Slatopolsky E, Finch J, Clay P, Martin D, Sicard G, Singer G, et al. A novel mechanism for skeletal resistance in uremia. Kidney Int 2000; 58: 753-76I.

5I. Salusky IB, Goodman WG, Kuizon BD, Lavigne JR, Zahranik RJ, Gales B, et al. Similar predictive value of bone turnover using first- and second-generation immunometric PTH assays in pediatric patients treated with peritoneal dialysis. Kidney Int 2003; 63: | $80|-| 808$

52. Au AY, McDonald K, Gill A, Sywak M, Diamond $T$, Conigrave AD, et al. PTH mutation with primary hyperparathyroidism and undetectable intact PTH. N Engl J Med 2008; 359: | | 84- | | 86.

53. Hocher B, Armbruster FP, Stoeva S, Reichetzeder C, Gron HJ, Lieker I, et al. Measuring parathyroid hormone (PTH) in patients with oxidative stress-do we need a fourth generation parathyroid hormone assay? PLoS One 2012; 7: e40242.

54. Hocher B, Oberthur D, Slowinski T, Querfeld U, Schaefer F, Doyon A, et al. Modeling of oxidized PTH (oxPTH) and non-oxidized PTH (n-oxPTH) receptor binding and relationship of oxidized to non-oxidized PTH in children with chronic renal failure, adult patients on hemodialysis and kidney transplant recipients. Kidney Blood Press Res 2013; 37: 240-25I.

55. Silverberg SJ, Gao P, Brown I, LoGerfo P, Cantor TL, Bilezikian JP. Clinical utility of an immunoradiometric assay for parathyroid hormone ( I-84) in primary hyperparathyroidism. J Clin Endocrinol Metab 2003; 88: 4725-4730.

56. Tepel M, Armbruster FP, Gron HJ, Scholze A Reichetzeder C, Roth HJ, et al. Nonoxidized, biologically active parathyroid hormone determines mortality in hemodialysis patients. I Clin Endocrinol Metab 20।3; 98: 4744-475।.

57. Cioffi M, Corradino M, Gazzerro P, Vietri MT, Di Macchia C, Contursi A, et al. Serum concentrations of intact parathyroid hormone in healthy children. Clin Chem 2000; 46: 863-864.

58. Souberbielle JC, Massart C, Brailly-Tabard S, Cormier C, Cavalier E, Delanaye P, et al. Serum PTH reference values established by an automated third-generation assay in vitamin D-replete subjects with normal renal function: consequences of diagnosing primary hyperparathyroidism and the classification of dialysis patients. Eur J Endocrinol 2016; 174: 315-323.

59. Bikle DD, Stesin A, Halloran B, Steinbach L, Recker R. Alcohol-induced bone disease: relationship to age and parathyroid hormone levels. Alcohol Clin Exp Res 1993; 17: 690-695.

60. Lindholm J, Steiniche T, Rasmussen E, Thamsborg $\mathrm{G}$, Nielsen IO, Brockstedt-Rasmussen $\mathrm{H}$, et al. Bone disorder in men with chronic alcoholism: a reversible disease? J Clin Endocrinol Metab 1991; 73: I 18-124.

61. Specker BL, Tsang RC, Ho ML. Changes in calcium 
homeostasis over the first year postpartum: effect of lactation and weaning. Obstet Gynecol 1991; 78: 56-62.

62. Cavalier E, Carlisi A, Chapelle JP, Delanaye P. False positive PTH results: an easy strategy to test and detect analytical interferences in routine practice. Clin Chim Acta 2008; 387: I 50- I 52.

63. Goldstein RE, Blevins L, Delbeke D, Martin WH. Effect of minimally invasive radioguided parathyroidectomy on efficacy, length of stay, and costs in the management of primary hyperparathyroidism. Ann Surg 2000; 231: 732-742.

64. Bilezikian JP, Cusano NE, Khan AA, Liu JM, Marcocci C, Bandeira F. Primary hyperparathyroidism. Nat Rev Dis Primers 2016; 2: 16033.

65. Sokoll LJ, Drew H, Udelsman R. Intraoperative parathyroid hormone analysis: A study of 200 consecutive cases. Clin Chem 2000; 46: 1662-1668.

66. Tan K, Ong L, Sethi SK, Saw S. Comparison of the Elecsys PTH(I-84) assay with four contemporary second generation intact PTH assays and association with other biomarkers in chronic kidney disease patients. Clin Biochem 2013; 46: 78I-786.

67. Joly D, Drueke TB, Alberti C, Houillier P, Lawson-Body $\mathrm{E}$, Martin $\mathrm{KJ}$, et al. Variation in serum and plasma PTH levels in second-generation assays in hemodialysis patients: a cross-sectional study. Am J Kidney Dis 2008; 51: 987-995.

68. Levin O, Morris LF, Wah DT, Butch AW, Yeh MW. Falsely elevated plasma parathyroid hormone level mimicking tertiary hyperparathyroidism. Endocr Pract 201 I; 17: e8-। I.

69. Yin JJ, Selander K, Chirgwin JM, Dallas M, Grubbs BG, Wieser R, et al. TGF-beta signaling blockade inhibits PTHrP secretion by breast cancer cells and bone metastases development. J Clin Invest 1999; 103: 197-206.

70. Care AD, Bruce JB, Boelkins J, Kenny AD, Conaway H, Anast CS. Role of pancreozymin-cholecystokinin and structurally related compounds as calcitonin secretogogues. Endocrinology 1971; 89: 262-27I.

7I. Berson SA, Yalow RS, Aurbach GD, Potts JT. Immunoassay of Bovine and Human Parathyroid Hormone. Proc Natl Acad Sci U S A 1963; 49: 613-617.

72. Masi L, Brandi ML. Calcitonin and calcitonin receptors. Clin Cases Miner Bone Metab 2007; 4: 117 122.

73. Cianferotti L, Marcocci C. Subclinical vitamin D deficiency. Best Pract Res Clin Endocrinol Metab 2012; 26: 523-537.

74. Papapoulos SE, Clemens TL, Sandler LM, Fra- her LJ, Winer J, O'Riordan JL. The effect of renal function on changes in circulating concentrations of 1,25-dihydroxycholecalciferol after an oral dose. Clin Sci (Lond) 1982; 62: 427-429.

75. Mithal A, Wahl DA, Bonjour JP, Burckhardt $\mathrm{P}$, Dawson-Hughes B, Eisman JA, et al. Global vitamin $D$ status and determinants of hypovitaminosis D. Osteoporos Int 2009; 20: 1807-1820.

76. Yetley EA. Assessing the vitamin D status of the US population. Am J Clin Nutr 2008; 88: 558S-564S.

77. Forrest KY, Stuhldreher WL. Prevalence and correlates of vitamin $D$ deficiency in US adults. Nutr Res 201 I; 31: 48-54.

78. Schiavi SC, Kumar R. The phosphatonin pathway: new insights in phosphate homeostasis. Kidney Int 2004; 65: I- 14 .

79. Silver J, Naveh-Many T. FGF-23 and secondary hyperparathyroidism in chronic kidney disease. Nat Rev Nephrol 2013; 9: 64I-649.

80. Kida Y. Fibroblast growth factor 23 in oncogenic osteomalacia and X-linked hypophosphatemia. N Engl J Med 2003; 349: 505-506; author reply 505506.

8I. Fukumoto S. Diagnostic Modalities for FGF23-Producing Tumors in Patients with Tumor-Induced Osteomalacia. Endocrinol Metab (Seoul) 2014; 29: 136-143.

82. Araya K, Fukumoto S, Backenroth R, Takeuchi $\mathrm{Y}$, Nakayama $\mathrm{K}$, Ito $\mathrm{N}$, et al. A novel mutation in fibroblast growth factor 23 gene as a cause of tumoral calcinosis. J Clin Endocrinol Metab 2005; 90: 5523-5527.

83. Roetzer KM, Varga F, Zwettler E, Nawrot-Wawrzyniak K, Haller J, Forster E, et al. Novel PHEX mutation associated with hypophosphatemic rickets. Nephron Physiol 2007; 106: p8- 12.

84. Ichikawa S, Traxler EA, Estwick SA, Curry LR, Johnson ML, Sorenson $\mathrm{AH}$, et al. Mutational survey of the $\mathrm{PHEX}$ gene in patients with $\mathrm{X}$-linked hypophosphatemic rickets. Bone 2008; 43: 663-666.

85. Masi L, Gozzini A, Franchi A, Campanacci D, Amedei A, Falchetti A, et al. A novel recessive mutation of fibroblast growth factor-23 in tumoral calcinosis. J Bone Joint Surg Am 2009; 91: I 190-। 198.

86. Bahrami A, Weiss SW, Montgomery E, Horvai $A E$, Jin L, Inwards CY, et al. RT-PCR analysis for FGF23 using paraffin sections in the diagnosis of phosphaturic mesenchymal tumors with and without known tumor induced osteomalacia. Am J Surg Pathol 2009; 33: I348- I 354.

87. Wesseling-Perry K. FGF23: is it ready for prime time? Clin Chem 20 I : 57: | 476- 477. 


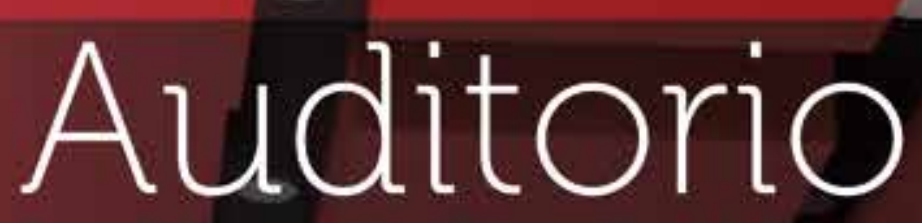

\section{Un espacio a su servicio}

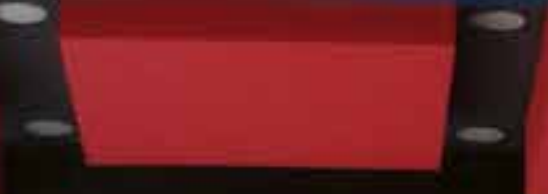

Auditorio tipo teatro

Ideal para convenciones, reuniones empresariales, conferencias, seminarios,

cursos, foros y muestras comerciales

Capacidad para 150 personas

Sistema de sonido acústico profesional

Parqueadero robotizado para 95 vehiculos

Ubicado en el moderno edificio del Laboratorio Clínico Hematológico
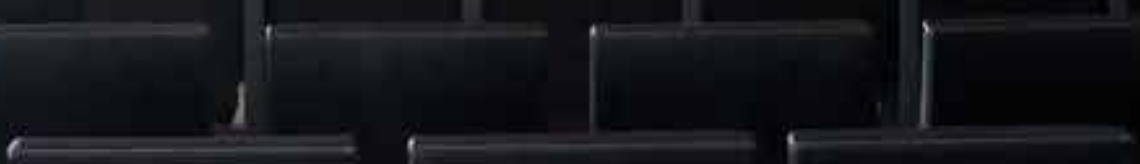

Carrera 43 C \# 5 - 33. Patio Bonito, El Poblado Medellin - Antioquia

Mayor información: 4444900

EDIMECO

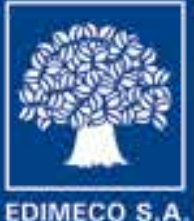

